\title{
Phytochemical Analysis of Phenolics, Sterols, and Terpenes in Colored Wheat Grains by Liquid Chromatography with Tandem Mass Spectrometry
}

\author{
Mayya P. Razgonova 1,*(D), Alexander M. Zakharenko ${ }^{1}$, Elena I. Gordeeva ${ }^{1,2}$, Olesya Yu. Shoeva ${ }^{1,2, *(D)}$, \\ Elena V. Antonova ${ }^{1,3}{ }^{(D}$, Konstantin S. Pikula ${ }^{1}\left(\mathbb{D}\right.$, Liudmila A. Koval ${ }^{4}$, Elena K. Khlestkina ${ }^{1,2, * \mathbb{D}}$ and \\ Kirill S. Golokhvast 1,4,5,6,*
}

Citation: Razgonova, M.P.; Zakharenko, A.M.; Gordeeva, E.I.; Shoeva, O.Y.; Antonova, E.V.; Pikula, K.S.; Koval, L.A.; Khlestkina, E.K.; Golokhvast, K.S. Phytochemical Analysis of Phenolics, Sterols, and Terpenes in Colored Wheat Grains by Liquid Chromatography with Tandem Mass Spectrometry. Molecules 2021, 26, 5580. https://doi.org/ $10.3390 /$ molecules 26185580

Academic Editor: Francesco Cacciola

Received: 15 August 2021

Accepted: 7 September 2021

Published: 14 September 2021

Publisher's Note: MDPI stays neutral with regard to jurisdictional claims in published maps and institutional affiliations.

Copyright: (c) 2021 by the authors. Licensee MDPI, Basel, Switzerland. This article is an open access article distributed under the terms and conditions of the Creative Commons Attribution (CC BY) license (https:/ / creativecommons.org/licenses/by/ $4.0 /)$.
1 N.I. Vavilov All-Russian Institute of Plant Genetic Resources, B. Morskaya 42-44, 190000 Saint Petersburg, Russia; zakharenko.am@dvfu.ru (A.M.Z.); elgordeeva@bionet.nsc.ru (E.I.G.); selena@ipae.uran.ru (E.V.A.); pikula_ks@dvfu.ru (K.S.P.)

2 Institute of Cytology and Genetics, Siberian Branch of Russian Academy of Sciences, Lavrentjeva 10, 630090 Novosibirsk, Russia

3 Institute of Plant and Animal Ecology, Ural Branch of Russian Academy of Sciences, 8 Marta 202, 620144 Ekaterinburg, Russia

4 School of Biomedicine, Far Eastern Federal University, Sukhanova 8, 690950 Vladivostok, Russia; koval.liudmila.an@mail.ru

5 Pacific Geographical Institute, Far Eastern Branch of the Russian Academy of Sciences, Radio 7, 690041 Vladivostok, Russia

6 Siberian Federal Scientific Centre of Agrobiotechnology, Centralnaya, Presidium, 633501 Krasnoobsk, Russia

* Correspondence: m.razgonova@vir.nw.ru (M.P.R.); olesya_ter@bionet.nsc.ru (O.Y.S.); director@vir.nw.ru (E.K.K.); golokhvast.ks@vir.nw.ru or golokhvast@sfsca.ru (K.S.G.)

Abstract: The colored grain of wheat (Triticum aestivum L.) contains a large number of polyphenolic compounds that are biologically active ingredients. The purpose of this work was a comparative metabolomic study of extracts from anthocyaninless (control), blue, and deep purple (referred to here as black) grains of seven genetically related wheat lines developed for the grain anthocyanin pigmentation trait. To identify target analytes in ethanol extracts, high-performance liquid chromatography was used in combination with Bruker Daltonics ion trap mass spectrometry. The results showed the presence of 125 biologically active compounds of a phenolic (85) and nonphenolic (40) nature in the grains of T. aestivum (seven lines). Among them, a number of phenolic compounds affiliated with anthocyanins, coumarins, dihydrochalcones, flavan-3-ols, flavanone, flavones, flavonols, hydroxybenzoic acids, hydroxycinnamic acids, isoflavone, lignans, other phenolic acids, stilbenes, and nonphenolic compounds affiliated with alkaloids, carboxylic acids, carotenoids, diterpenoids, essential amino acids, triterpenoids, sterols, nonessential amino acids, phytohormones, purines, and thromboxane receptor antagonists were found in T. aestivum grains for the first time. A comparative analysis of the diversity of the compounds revealed that the lines do not differ from each other in the proportion of phenolic (53.3\% to $70.3 \%$ of the total number of identified compounds) and nonphenolic compounds ( $46.7 \%$ to $29.7 \%$ ), but diversity of the compounds was significantly lower in grains of the control line. Even though the lines are genetically closely related and possess similar chemical profiles, some line-specific individual compounds were identified that constitute unique chemical fingerprints and allow to distinguish each line from the six others. Finally, the influence of the genotype on the chemical profiles of the wheat grains is discussed.

Keywords: Triticum aestivum; colored wheat; anthocyanin; HPLC-MS/MS; tandem mass spectrometry; phenolic compound; biologically active compound

\section{Introduction}

Among nutritional sources of antioxidant compounds necessary for human health, cereal products, which contain flavonoid pigments (plant compounds of a phenolic na- 
ture), are now receiving increasing attention [1]. The biosynthesis of various colored flavonoid compounds in certain grain components of cereal plants gives rise to a distinct color (Figure 1). As a result of the biosynthesis of anthocyanins, cereal seeds can have a color of various shades from bluish gray and reddish to dark purple and almost black. Other classes of flavonoid compounds give the grain a reddish-brown color (proanthocyanidins) or a dark-brown color (phlobaphenes). Anthocyanins have the highest antioxidant potential among the above-mentioned compounds [2]. These substances can accumulate in vegetative and reproductive parts of the plant, where their main physiological role is to protect the plant from excessive UV radiation. Additionally, the concentration of anthocyanins usually increases during exposure to adverse environmental factors [3].

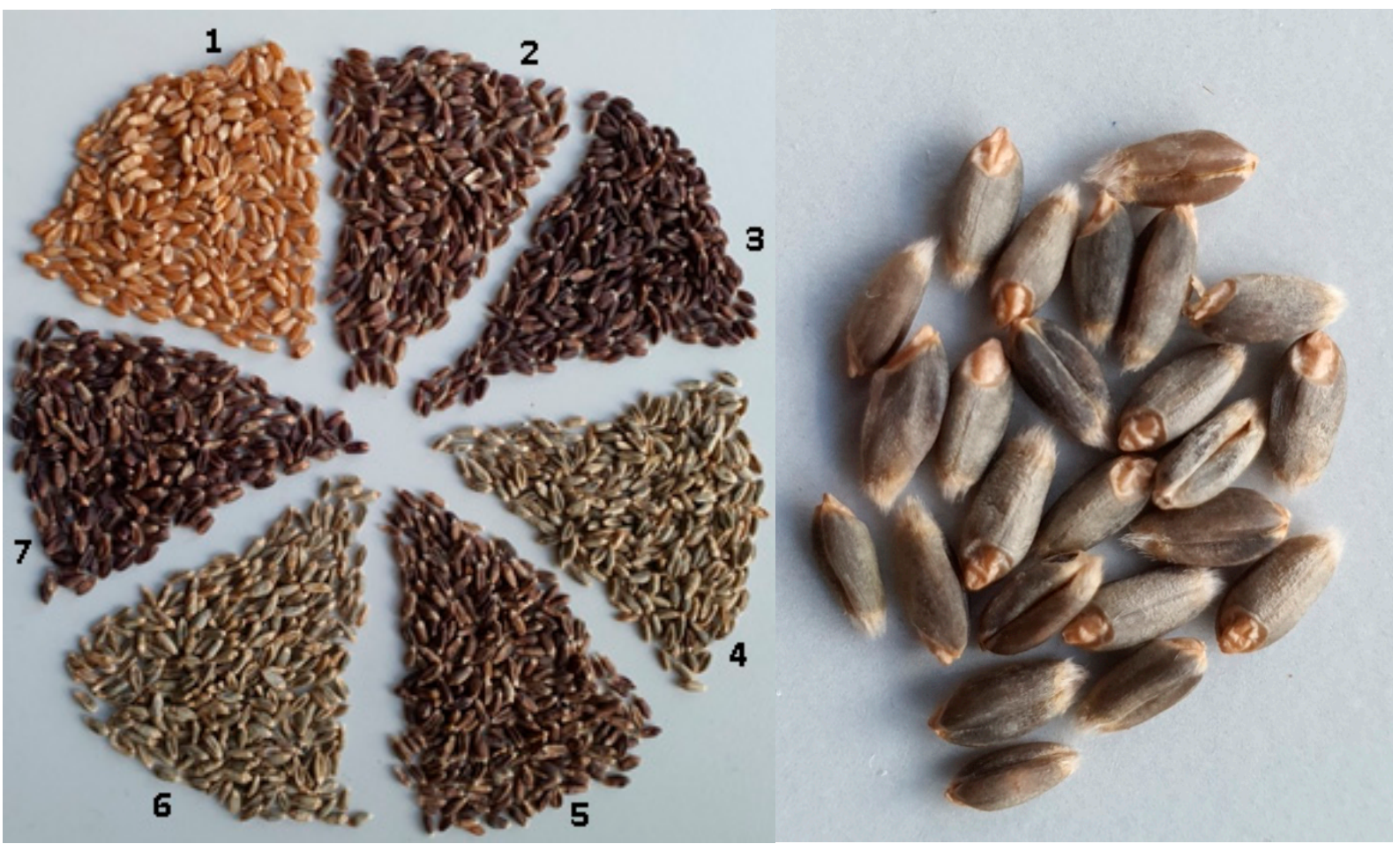

(A)

(B)

Figure 1. Diversity of colors among the analyzed wheat lines (having anthocyanin-rich grains). (A) The grains of the wheat lines used in this study: control line Saratovskaya 29 (S29) (1) in the upper left-hand corner and next in clockwise order S29 BLACK (4Th-4B) (2), S29 BLACK (4Th-4D) (3), S29 BLUE (4Th-4D) (4), BW BLACK (4Th-4D) (5), S29 BLUE (4Th-4B) (6), and E22 BLACK (4Th-4D) (7). (B) Grains of S29 BLUE (4Th-4B).

Anthocyanins have been shown to play an important part in the prevention of neurodegenerative diseases [4], atherosclerosis, diabetes, and obesity and to have vasoprotective and anti-inflammatory properties [5,6]. As a consequence, the food industry is interested in researching colored cereals.

In the most common cereal species, soft wheat (Triticum aestivum L.), the grain can have either an unremarkable color or a reddish-brown, bluish-gray, or purple hue. The differences in color are due to the accumulation of certain flavonoid pigments in various layers of wheat grain envelopes [7-9]. The biosynthesis of proanthocyanidins in the seed coat causes a reddish-brown hue (trait: "red grain") and is controlled by $R$ genes localized on chromosomes of homoeologous group 3 [10]. The bluish-gray hue appears to be due to the biosynthesis of anthocyanins in the aleurone layer (trait: "blue aleurone") and is regulated by $B a$ genes introduced into the common wheat genome from wild relatives such as wheatgrass Thinopyrum ponticum, Triticum boeoticum, and Thinopyrum bessarabicum owing to translocations in the chromosomes of homoeologous group 4 or via a substitution of one of the chromosomes of homoeologous group 4 [11-13]. The purple color is a consequence 
of the biosynthesis of anthocyanins in cells of the pericarp (trait: "purple pericarp"). This trait is regulated by two complementary genes, $P p-1$ and $P p 3$, mapped to chromosomes of homoeologous group 7 and chromosome $2 \mathrm{~A}$, respectively $[8,14,15]$. The inclusion of the genes that control the biosynthesis of anthocyanins in the grain into the breeding process may ultimately increase nutritional value of whole-grain products $[1,16]$. This notion has been demonstrated in end-use bakery products prepared from anthocyaninrich wheat grains such as whole-grain bread [17,18], biscuits [16,19], pasta [20], pancakes, porridge, crackers, and candy bars [21]. The amount of anthocyanins in whole-grain blue-wheat bread and purple-wheat bread made according to a traditional Czech recipe has been determined, and how thermal parameters, such as temperature and baking time, affect individual anthocyanins and the total amount of anthocyanins in bread has been shown [18].

The predominant anthocyanin in purple and blue wheat varieties is cyanidin-3glycoside, and each wheat variety is reported to have a specific anthocyanin profile [22]. Thirteen anthocyanins have been identified in purple wheat, among which cyanidin3-glucoside is the most abundant, followed by cyanidin-3-galactoside and malvidin-3glucoside. In purple wheat, anthocyanins are also present in the form of pelargonidin-3glucoside and anthocyanins glycosylated with arabinose [23]. Besides anthocyanins, other bioactive phytochemicals such as phenolic acids, carotenoids, tocopherols, and phytosterols can be found in the wheat grain [24], and determination of their profiles in colored wheat grains will allow to take full practical advantage of colored wheat varieties. Therefore, the aim of this study was to identify anthocyanins and the total polyphenolic profile along with accompanying sterols and stilbenes in seven wheat lines having grains of different colors by high-performance liquid chromatography (HPLC) coupled with tandem mass spectrometry (MS/MS) on an ion trap instrument. The lines have been previously developed for the grain anthocyanin pigmentation trait in a common genetic background of anthocyaninless cultivar Saratovskaya 29 (S29) (four lines) used here as a control and in the genetic background of the breeding lines promising in terms of cultivation in Western Siberia (two lines). Two blue-grained lines-S29 BLUE (4Th-4B) and S29 BLUE (4Th-4D)are substitution lines where chromosomes $4 \mathrm{~B}$ and $4 \mathrm{D}$ are substituted with Th. ponticum chromosome 4Th carrying the $B a$ gene determining the blue pigmentation of grains $[25,26]$. Two deep-purple-grained, i.e., almost black-grained lines-S29 BLACK (4Th-4B) and S29 BLACK (4Th-4D) - in addition to chromosomes $4 \mathrm{~B}$ and $4 \mathrm{D}$ substituted with $4 \mathrm{Th}$, feature introgressions in chromosomes 7D and 2A, where the dominant alleles of genes $P p-D 1$ and $P p 3$, respectively, are located [25]. Two other black-grained lines-BW BLACK (4Th-4D) and E22 BLACK (4Th-4D)-were developed in the genetic background of breeding line BW49880 (BW) and cv. Element 22 (E22), respectively, by means of S29 sister lines as donors of genes $P p$ and $B a$ in the current study. The use of such genetically related lines in a metabolomic study should enable us to draw conclusions about the effects of chromosome substitutions and introgression fragments on the chemical profile of the grains. To our knowledge, this is the first extensive study on anthocyanins and related polyphenols in unpigmented, blue-grained, and purple-grained wheat lines.

\section{Results}

\subsection{Chemical Identification of the Wheat Grain Metabolites}

A total of 300 peaks were detected in the chromatogram (Figure 2). After a comparison of the $m / z$ values, retention times, and the fragmentation patterns with the MS/MS spectral data retrieved from the cited articles and after a database search (MS2T, MassBank, HMDB), a comprehensive table was compiled of the molecular masses of the analytes of interest isolated from ethanolic extracts of $T$. aestivum grains for ease of annotation (Appendix A). The 125 identified biologically active compounds are presented in Table 1 . Among them, 85 compounds belong to various polyphenolic families: anthocyanins, flavones, flavonols, flavan-3-ols, flavanones, hydroxycinnamic acids, hydroxybenzoic acids, stilbenes, and coumarins, and the other 40 compounds are nonphe- 
nolic substances. In addition to previously reported metabolites, a number of metabolites were found for the first time in T. aestivum grains. Among them, there were anthocyanins (cyanidin 3-(2"'-galloylglucoside) and petunidin), coumarins (fraxetin and fraxetin-7-O-sulfate), dihydrochalcones (phlorizin), flavan-3-ols (epicatechin and gallocatechin), flavanone (naringenin), flavones (acacetin C-glucoside methylmalonylated, apigenin, apigenin 6-C-deoxyhexoside-8-C-pentoside, dihydroxy tetramethoxyflavanone, cirsiliol, genistein $C$-glucosylglucoside, hydroxy dimethoxyflavone hexoside, myricetin, orientin 7-O-deoxyhexoside, pentahydroxy dimethoxyflavone, pentahydroxy dimethoxyflavone hexoside, pentahydroxy trimethoxy flavone, tetrahydroxy-dimethoxyflavone-hexoside, trihydroxy methoxyflavone triacetate, and vitexin $6^{\prime \prime}$-O-glucoside), flavonols (ampelopsin, isorhamnetin, kaempferide, kaempferol, rhamnetin I, rhamnetin II, taxifolin-3-O-glucoside, and taxifolin-O-pentoside), hydroxybenzoic acids (cis-salvianolic acid J, gallic acid hexoside, hydroxy methoxy dimethylbenzoic acid, salvianolic acid D, salvianolic acid F, and salvianolic acid G), hydroxycinnamic acids (1-caffeoyl- $\beta$-D-glucose, 1-O-Sinapoyl- $\beta$-Dglucose, caffeic acid derivative, caftaric acid, and ferulic acid methyl ester), isoflavone (wighteone-O-glucoside), lignans (dimethyl-secoisolariciresinol, podophyllotoxin), other phenolic acids (1-O-caffeoyl-5-O-feruloylquinic acid, 4-O-Caffeoyl-5-O- $p$-coumaroylquinic acid, and feruloyl sulfate), stilbenes (pinosylvin, polydatin, and resveratrol), alkaloids (berberine and sespendole), carboxylic acids (9,10-dihydroxy-8-oxooctadec-12-enoic acid, 11-hydroperoxy-octadecatrienoic acid, dihydroxy docosanoic acid, docosenoic acid, myristoleic acid, pentacosenoic acid, salvianic acid $C$, and undecanedioic acid), carotenoids (cryptoxanthin and (3S, $3^{\prime} S$, all-E)-zeaxanthin), diterpenoids (isocryptotanshinone II and tanshinone IIB), essential amino acids (L-histidine, L-tryptophan, and L-valine), triterpenoids ( $\beta$-amyrin, squalene, uvaol, and ursolic acid), sterols (avenasterol, brassicasterol, $\beta$-sitostenone, $\beta$-sitosterin, campestenone, ergosterol, fucosterol, oxo-hydroxy sitosterol, vebonol), steroids (cyclopassifloic acid glucoside), nonessential amino acids (tyrosine), phytohormone (GA8-hexose gibberellin), propionic acid (ketoprofen), purine (adenosine), and thromboxane receptor antagonist (vapiprost).

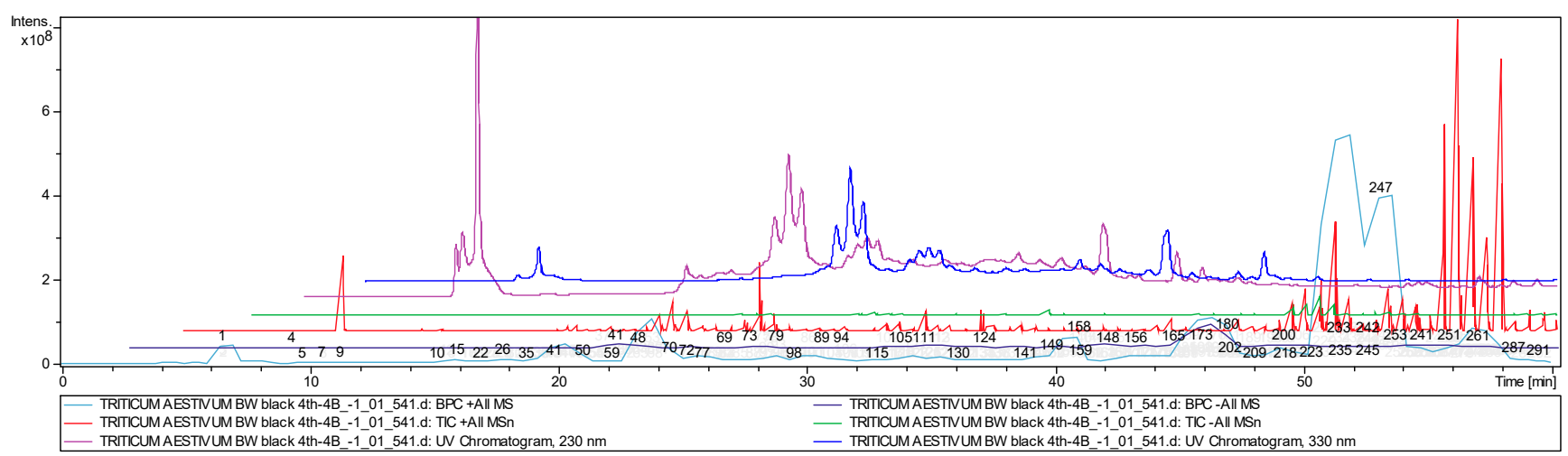

Figure 2. Chemical profiles of the BW BLACK (4Th-4D) sample presented as a total ion chromatogram from the EtOH extract.

The flavone family featured the greatest number of members (32 substances) among the analyzed wheat grains; the flavonol family (10), anthocyanins (10), cinnamic acids (seven), lignin (five), and hydroxybenzoic acids (six) were found much less frequently. Among other identified compounds, i.e., nonphenolic substances, sterols (six compounds), higher-molecular-weight carboxylic acids (seven), and di- and triterpenoids (eight) were detected most often. 
Table 1. A detailed table of the biologically active substances found in the analyzed colored-grain lines of the wheat $T$. aestivum. Different color marks the presence of certain compounds in particular lines.

\begin{tabular}{|c|c|c|c|c|c|c|c|c|c|}
\hline ID & $\begin{array}{l}\text { Classes and } \\
\text { Families of } \\
\text { Compounds }\end{array}$ & Name & $\begin{array}{c}\text { S29 } \\
\text { Control }\end{array}$ & $\begin{array}{c}\text { S29 } \\
\text { BLUE } \\
\text { 4Th-4B }\end{array}$ & $\begin{array}{c}\text { S29 } \\
\text { BLUE } \\
\text { 4Th-4D }\end{array}$ & $\begin{array}{c}\text { S29 } \\
\text { BLACK } \\
\text { 4Th-4B }\end{array}$ & $\begin{array}{c}\text { S29 } \\
\text { BLACK } \\
\text { 4Th-4D }\end{array}$ & $\begin{array}{c}\text { E22 } \\
\text { BLACK } \\
\text { 4Th-4D }\end{array}$ & $\begin{array}{l}\text { BW } \\
\text { BLACK } \\
\text { 4Th-4D }\end{array}$ \\
\hline & Phenolics & & & & & & & & \\
\hline 1 & Anthocyanin & $\begin{array}{l}\text { Cyanidin } \\
\text { 3-(2"-galloylglucoside) }\end{array}$ & & & & & & & yes \\
\hline 2 & & $\begin{array}{l}\text { Cyanidin-3-O-3" } 3^{\prime \prime}, 6^{\prime \prime}-O- \\
\text { Dimalonylglucoside }\end{array}$ & & yes & & yes & & yes & \\
\hline 3 & & Cyanidin-3-O-glucoside & & & & & yes & & \\
\hline 4 & & Malvidin 3-O-rutinoside & & & & & yes & & \\
\hline 5 & & $\begin{array}{l}\text { Malvidin 3-O-rutinoside- } \\
\text { 5-O-glucoside }\end{array}$ & & yes & yes & & & & \\
\hline 6 & & Peonidin 3-O-rutinoside & & yes & & & yes & & \\
\hline 7 & & $\begin{array}{l}\text { Peonidin } \\
\text { 3-rutinoside-5-glucoside }\end{array}$ & & & & & & & yes \\
\hline 8 & & Peonidin-3-O-glucoside & & & & & yes & & yes \\
\hline 9 & & Petunidin & yes & & & & & yes & \\
\hline 10 & & $\begin{array}{l}\text { Petunidin 3-O-rutinoside- } \\
\text { 5-O-glucoside }\end{array}$ & & yes & yes & & & & \\
\hline 11 & $\begin{array}{l}\text { Cinnamic acid } \\
\text { derivative }\end{array}$ & Ferulic acid methyl ester & & & & & yes & & \\
\hline 12 & $\begin{array}{l}\text { Hydroxycinnamic } \\
\text { acid }\end{array}$ & 1-Caffeoyl- $\beta$-D-glucose & & & & & yes & & \\
\hline 13 & & $\begin{array}{l}\text { 1-O-Sinapoyl- } \beta-\mathrm{D}- \\
\text { glucose }\end{array}$ & & & & & yes & & \\
\hline 14 & & Caffeic acid derivative & & & & & yes & & yes \\
\hline 15 & & Caftaric acid & & yes & yes & & & yes & yes \\
\hline 16 & & Chlorogenic acid & & & & & yes & & \\
\hline 17 & & Ferulic acid & yes & & & & yes & yes & \\
\hline 18 & Coumarin & Fraxetin & & yes & & & & & \\
\hline 19 & & Fraxetin-7-O-sulfate & & yes & & & & & \\
\hline 20 & Dihydrochalcone & Phlorizin & & & & & & & yes \\
\hline 21 & Flavan-3-ol & Catechin [D-Catechol] & & yes & & & & & yes \\
\hline 22 & & Epicatechin & & & & & & & yes \\
\hline 23 & & $\begin{array}{l}\text { Gallocatechin } \\
\text { [+(-)Gallocatechin] }\end{array}$ & & & & yes & & & yes \\
\hline 24 & Flavanone & $\begin{array}{l}\text { Naringenin [Naringetol; } \\
\text { Naringenine] }\end{array}$ & & & yes & yes & & yes & yes \\
\hline 25 & Flavone & $\begin{array}{l}\text { 6-C-hexosyl-chrysoeriol } \\
\text { O-rhamnoside-O- } \\
\text { hexoside }\end{array}$ & yes & yes & & yes & yes & yes & \\
\hline 26 & & $\begin{array}{l}\text { Acacetin } C \text {-glucoside } \\
\text { methyl malonylated }\end{array}$ & & & & & yes & & \\
\hline 27 & & Apigenin & & & yes & & yes & & yes \\
\hline 28 & & $\begin{array}{l}\text { Apigenin } 2^{\prime \prime} \text {-O-sinapoyl, } \\
\text { C-hexosyl, C-pentosyl }\end{array}$ & & yes & yes & & & & \\
\hline 29 & & $\begin{array}{l}\text { Apigenin } \\
\text { 6,8-di-C-pentoside }\end{array}$ & & yes & yes & yes & yes & & \\
\hline 30 & & $\begin{array}{l}\text { Apigenin } \\
\text { 6-C-deoxyhexoside-8-C- } \\
\text { pentoside }\end{array}$ & & & & yes & & & yes \\
\hline 31 & & $\begin{array}{l}\text { Apigenin-6-C- } \beta- \\
\text { galactosyl-8-C- } \beta- \\
\text { glycosyl-O- } \\
\text { glycuronopyranoside }\end{array}$ & & & & & & & yes \\
\hline 32 & & $\begin{array}{l}\text { Apigenin 8-C-hexoside-6- } \\
\text { C-pentoside }\end{array}$ & yes & yes & yes & yes & yes & yes & yes \\
\hline 33 & & $\begin{array}{l}\text { Apigenin 8-C-pentoside-6- } \\
\text { C-hexoside }\end{array}$ & & yes & yes & yes & yes & yes & \\
\hline 34 & & Chrysoeriol [Chryseriol] & & yes & yes & yes & yes & yes & yes \\
\hline 35 & & $\begin{array}{l}\text { Chrysoeriol } \\
\text { C-hexoside-C-pentoside }\end{array}$ & & yes & & & yes & & \\
\hline 36 & & Cirsiliol & yes & & & & & & \\
\hline 37 & & $\begin{array}{l}\text { Dihydroxy } \\
\text { tetramethoxyflavone }\end{array}$ & & & yes & & & & \\
\hline 38 & & Diosmetin & & & & & & & yes \\
\hline
\end{tabular}


Table 1. Cont

\begin{tabular}{|c|c|c|c|c|c|c|c|c|c|}
\hline ID & $\begin{array}{l}\text { Classes and } \\
\text { Families of } \\
\text { Compounds }\end{array}$ & Name & $\begin{array}{c}\text { S29 } \\
\text { Control }\end{array}$ & $\begin{array}{c}\text { S29 } \\
\text { BLUE } \\
\text { 4Th-4B }\end{array}$ & $\begin{array}{c}\text { S29 } \\
\text { BLUE } \\
\text { 4Th-4D }\end{array}$ & $\begin{array}{c}\text { S29 } \\
\text { BLACK } \\
\text { 4Th-4B }\end{array}$ & $\begin{array}{c}\text { S29 } \\
\text { BLACK } \\
\text { 4Th-4D }\end{array}$ & $\begin{array}{c}\text { E22 } \\
\text { BLACK } \\
\text { 4Th-4D }\end{array}$ & $\begin{array}{c}\text { BW } \\
\text { BLACK } \\
\text { 4Th-4D }\end{array}$ \\
\hline 39 & & $\begin{array}{l}\text { Genistein C-glucosyl } \\
\text { glucoside }\end{array}$ & & & & & yes & & \\
\hline 40 & & $\begin{array}{l}\text { Hydroxy } \\
\text { dimethoxyflavone } \\
\text { hexoside }\end{array}$ & & & & & yes & & \\
\hline 41 & & Luteolin & & & & & yes & & \\
\hline 42 & & Luteolin 8-C-Glucoside & & & & & & yes & \\
\hline 43 & & $\begin{array}{l}\text { Luteolin 8-C-hexoside-6- } \\
\text { C-pentoside }\end{array}$ & & & & & & & yes \\
\hline 44 & & $\begin{array}{l}\text { Luteolin 8-C-pentoside-6- } \\
\text { C-hexoside }\end{array}$ & & yes & yes & yes & yes & & \\
\hline 45 & & Myricetin & & & & yes & & & \\
\hline 46 & & $\begin{array}{l}\text { Orientin } \\
\text { 7-O-deoxyhexoside } \\
\text { [Luteolin 8-C-glucoside } \\
\text { 7-O-deoxyhexoside] }\end{array}$ & & yes & & & & & \\
\hline 47 & & $\begin{array}{l}\text { Pentahydroxy } \\
\text { dimethoxyflavone }\end{array}$ & yes & & & & & & \\
\hline 48 & & $\begin{array}{l}\text { Pentahydroxy } \\
\text { dimethoxyflavone } \\
\text { hexoside }\end{array}$ & yes & & & & & yes & \\
\hline 49 & & $\begin{array}{l}\text { Pentahydroxy trimethoxy } \\
\text { flavone }\end{array}$ & yes & & & yes & yes & yes & yes \\
\hline 50 & & Tricin & & yes & yes & yes & yes & yes & yes \\
\hline 51 & & $\begin{array}{l}\text { Tetrahydroxy- } \\
\text { dimethoxyflavone- } \\
\text { hexoside }\end{array}$ & & yes & & & & & \\
\hline 52 & & $\begin{array}{l}\text { Trihydroxy } \\
\text { methoxyflavone triacetate }\end{array}$ & & & & & & yes & \\
\hline 53 & & $\begin{array}{l}\text { Vicenin-2 [Apigenin-6,8- } \\
\text { Di-C-Glucoside] }\end{array}$ & & yes & yes & & & & \\
\hline 54 & & $\begin{array}{l}\text { Vitexin } 2^{\prime \prime}-O \text {-glucoside } \\
\text { [Apigenin } 8 \text {-C-glucoside } \\
2^{\prime \prime} \text {-O-glucoside] }\end{array}$ & & yes & & & yes & & \\
\hline 55 & & $\begin{array}{l}\text { Vitexin } 6^{\prime \prime}-O \text {-glucoside } \\
\text { [Apigenin } 8 \text {-C-glucoside } \\
6^{\prime \prime} \text {-O-glucoside] }\end{array}$ & & & yes & yes & & & \\
\hline 56 & & Wighteone-O-glucoside & & & & & yes & & \\
\hline 57 & Flavonol & Ampelopsin & & & & & & & yes \\
\hline 58 & & Isorhamnetin & & & & & yes & yes & yes \\
\hline 59 & & Kaempferide & & & & & yes & & \\
\hline 60 & & Kaempferol & & & & & yes & yes & \\
\hline 61 & & Quercetin & & & & yes & & & \\
\hline 62 & & Rhamnetin I & & & & & & yes & \\
\hline 63 & & Rhamnetin II & & & & & yes & yes & \\
\hline 64 & & Selgin & & yes & & yes & & & \\
\hline 65 & & Taxifolin-3-O-glucoside & & yes & yes & yes & & yes & \\
\hline 66 & & Taxifolin-O-pentoside & & & & & yes & yes & yes \\
\hline 67 & Gallotannin & $\begin{array}{l}\beta \text {-Glucogallin [1-O- } \\
\text { Galloyl- } \beta \text {-D-Glucose] }\end{array}$ & yes & yes & yes & & yes & yes & \\
\hline 68 & $\begin{array}{l}\text { Hydroxybenzoic } \\
\text { acid }\end{array}$ & 4-Hydroxybenzoic acid & & yes & & & & & \\
\hline 69 & & Cis-salvianolic acid J & & yes & & & & yes & yes \\
\hline 70 & & $\begin{array}{l}\text { Hydroxy methoxy } \\
\text { dimethylbenzoic acid }\end{array}$ & & yes & & & & & yes \\
\hline 71 & & Salvianolic acid D & yes & yes & yes & yes & & yes & yes \\
\hline 72 & & Salvianolic acid F & & yes & & & & & \\
\hline 73 & & Salvianolic acid G & & & yes & & & yes & yes \\
\hline 74 & Lignan & $\begin{array}{l}\text { Dimethyl- } \\
\text { secoisolariciresinol }\end{array}$ & & & yes & & & & \\
\hline 75 & & Hinokinin & & yes & yes & yes & & yes & \\
\hline 76 & & Pinoresinol & & & & & & & yes \\
\hline
\end{tabular}


Table 1. Cont.

\begin{tabular}{|c|c|c|c|c|c|c|c|c|c|}
\hline ID & $\begin{array}{l}\text { Classes and } \\
\text { Families of } \\
\text { Compounds }\end{array}$ & Name & $\begin{array}{c}\text { S29 } \\
\text { Control }\end{array}$ & $\begin{array}{c}\text { S29 } \\
\text { BLUE } \\
\text { 4Th-4B }\end{array}$ & $\begin{array}{c}\text { S29 } \\
\text { BLUE } \\
\text { 4Th-4D }\end{array}$ & $\begin{array}{l}\text { S29 } \\
\text { BLACK } \\
\text { 4Th-4B }\end{array}$ & $\begin{array}{l}\text { S29 } \\
\text { BLACK } \\
\text { 4Th-4D }\end{array}$ & $\begin{array}{l}\text { E22 } \\
\text { BLACK } \\
\text { 4Th-4D }\end{array}$ & $\begin{array}{c}\text { BW } \\
\text { BLACK } \\
\text { 4Th-4D }\end{array}$ \\
\hline 77 & & $\begin{array}{l}\text { Podophyllotoxin } \\
\text { [Podofilox; Condylox; } \\
\text { Condyline; Podophyllinic } \\
\text { acid lactone] }\end{array}$ & & & & & yes & & \\
\hline 78 & & Syringaresinol & yes & yes & yes & & yes & & yes \\
\hline 79 & Phenolic acid & $\begin{array}{l}1-O \text {-caffeoyl-5-O- } \\
\text { feruloylquinic } \\
\text { acid }\end{array}$ & & yes & yes & yes & yes & & \\
\hline 80 & & $\begin{array}{l}\text { 4-O-Caffeoyl-5-O- } p \text { - } \\
\text { coumaroylquinic } \\
\text { acid }\end{array}$ & & & & & & & yes \\
\hline 81 & & Feruloyl sulfate & & yes & & & & & \\
\hline 82 & $\begin{array}{l}\text { Phenolic } \\
\text { glucoside }\end{array}$ & Gallic acid hexoside & yes & & & & & & \\
\hline 83 & Stilbene & Pinosylvin & & & yes & & & & \\
\hline 84 & & $\begin{array}{l}\text { Polydatin [Piceid; } \\
\text { trans-Piceid] }\end{array}$ & & & & & & yes & \\
\hline 85 & & Resveratrol & & & & & yes & & \\
\hline & Others & & & & & & & & \\
\hline 86 & $\begin{array}{l}\text { Alpha, omega- } \\
\text { dicarboxylic } \\
\text { acid }\end{array}$ & Undecanedioic acid & & & & & yes & & yes \\
\hline 87 & Carboxylic acid & $\begin{array}{l}\text { Myristoleic acid } \\
\text { [Cis-9-Tetradecanoic acid] }\end{array}$ & & yes & yes & yes & & yes & yes \\
\hline 88 & $\begin{array}{l}\text { Higher- } \\
\text { molecular- } \\
\text { weight carboxylic } \\
\text { acid }\end{array}$ & $\begin{array}{l}\text { 11-Hydroperoxy- } \\
\text { octadecatrienoic } \\
\text { acid }\end{array}$ & & & & & yes & & \\
\hline 89 & & $\begin{array}{l}\text { 9,10-Dihydroxy-8- } \\
\text { oxooctadec-12-enoic } \\
\text { acid }\end{array}$ & & yes & yes & yes & & & \\
\hline 90 & & $\begin{array}{l}\text { Dihydroxy docosanoic } \\
\text { acid }\end{array}$ & & yes & yes & yes & yes & yes & yes \\
\hline 91 & & $\begin{array}{l}\text { Docosenoic acid } \\
\text { [2-Docosenoic acid] }\end{array}$ & & & & & & & yes \\
\hline 92 & & $\begin{array}{l}\text { Hydroxy methoxy } \\
\text { dimethylbenzoic acid }\end{array}$ & & & & & yes & & \\
\hline 93 & & Pentacosenoic acid & yes & yes & yes & yes & yes & yes & yes \\
\hline 94 & & Salvianic acid C & & & yes & yes & yes & & yes \\
\hline 95 & Anabolic steroid & Vebonol & & yes & yes & & yes & & yes \\
\hline 96 & $\begin{array}{l}\text { Cycloartanol } \\
\text { [Steroids] }\end{array}$ & $\begin{array}{l}\text { Cyclopassifloic acid } \\
\text { glucoside }\end{array}$ & & & yes & & & yes & \\
\hline 97 & Carotenoid & $\begin{array}{l}\left(3 S, 3^{\prime} S, \text { all-E)-zeaxanthin }\right. \\
\text { [Zeaxanthin; } \\
\left(3 S, 3^{\prime} S\right) \text {-Zeaxanthin] }\end{array}$ & & yes & yes & & & yes & yes \\
\hline 98 & & $\begin{array}{l}\text { Cryptoxanthin } \\
{[\beta \text {-cryptoxanthin] }}\end{array}$ & & yes & & & yes & & \\
\hline 99 & Diterpenoid & Isocryptotanshinone II & & yes & yes & & & & \\
\hline 100 & & Tanshinone IIB & & & & & & & yes \\
\hline 101 & $\begin{array}{l}\text { Pentacyclic } \\
\text { diterpenoid }\end{array}$ & $\begin{array}{l}\beta \text {-Amyrin [ } \beta \text {-Amyrenol; } \\
\text { Amyrin] }\end{array}$ & & & & & & yes & \\
\hline 102 & & Gibberellic acid & & & yes & & & & \\
\hline 103 & Triterpenic acid & Betunolic acid & & & & & & & yes \\
\hline 104 & & Ursolic acid & & & & & & & yes \\
\hline 105 & Triterpenoid & Squalene & & yes & & & & & \\
\hline 106 & & Uvaol & & & & yes & & & \\
\hline 107 & $\begin{array}{l}\text { Essential amino } \\
\text { acid }\end{array}$ & L-Histidine & & yes & & & yes & & \\
\hline 108 & & $\begin{array}{l}\text { L-Tryptophan } \\
\text { [Tryptophan; } \\
\text { (S)-Tryptophan] }\end{array}$ & yes & yes & yes & yes & yes & yes & \\
\hline 109 & & L-Valine & & & yes & & & & \\
\hline 110 & $\begin{array}{l}\text { Nonessential } \\
\text { amino acid }\end{array}$ & Tyrosine & yes & & & & & & \\
\hline
\end{tabular}


Table 1. Cont.

\begin{tabular}{|c|c|c|c|c|c|c|c|c|c|}
\hline ID & $\begin{array}{l}\text { Classes and } \\
\text { Families of } \\
\text { Compounds }\end{array}$ & Name & $\begin{array}{c}\text { S29 } \\
\text { Control }\end{array}$ & $\begin{array}{c}\text { S29 } \\
\text { BLUE } \\
4 \text { Th-4B }\end{array}$ & $\begin{array}{c}\text { S29 } \\
\text { BLUE } \\
\text { 4Th-4D }\end{array}$ & $\begin{array}{c}\text { S29 } \\
\text { BLACK } \\
\text { 4Th-4B }\end{array}$ & $\begin{array}{c}\text { S29 } \\
\text { BLACK } \\
\text { 4Th-4D }\end{array}$ & $\begin{array}{c}\text { E22 } \\
\text { BLACK } \\
\text { 4Th-4D }\end{array}$ & $\begin{array}{l}\text { BW } \\
\text { BLACK } \\
4 \text { Th-4D }\end{array}$ \\
\hline 111 & $\begin{array}{l}\text { Indole } \\
\text { sesquiterpene } \\
\text { alkaloid }\end{array}$ & Sespendole & & & yes & & yes & & \\
\hline 112 & $\begin{array}{l}\text { Isoquinoline } \\
\text { alkaloid }\end{array}$ & $\begin{array}{l}\text { Berberine [Berberin; } \\
\text { Umbelletine; Berbericine] }\end{array}$ & & & & & yes & & yes \\
\hline 113 & Phytohormone & GA8-hexose gibberellin & yes & yes & yes & & yes & & yes \\
\hline 114 & $\begin{array}{l}\text { Sesquiterpenoid } \\
\text { plant hormone }\end{array}$ & $\begin{array}{l}\text { Abscisic acid [Dormin; } \\
\text { Abscisin II; } \\
\text { (S)-(+)-Abscisic acid] }\end{array}$ & & yes & & yes & & & \\
\hline 115 & Propionic acid & $\begin{array}{l}\text { Ketoprofen [Orudis; } 2-(3- \\
\text { Benzoylphenyl)Propionic } \\
\text { acid] }\end{array}$ & & yes & yes & yes & & & yes \\
\hline 116 & Purine & Adenosine & & yes & yes & & yes & & \\
\hline 117 & Phytosterol & $\begin{array}{l}\text { Ergosterol [Provitamin } \\
\text { D2; Ergosterin] }\end{array}$ & yes & yes & yes & yes & yes & yes & yes \\
\hline 118 & Sterol & Avenasterol & yes & yes & yes & yes & yes & yes & yes \\
\hline 119 & & $\begin{array}{l}\beta \text {-Sitostenone } \\
\text { [Stigmast-4-En-3-One; } \\
\text { Sitostenone] }\end{array}$ & & & yes & & yes & yes & \\
\hline 120 & & $\beta$-Sitosterin $[\beta$-Sitosterol] & & yes & & & yes & yes & \\
\hline 121 & & Campestenone & & yes & yes & yes & yes & & yes \\
\hline 122 & & Fucosterol & & yes & & yes & & & yes \\
\hline 123 & & Oxo-hydroxy sitosterol & & yes & & & & & \\
\hline 124 & $\begin{array}{l}\text { Thromboxane } \\
\text { receptor } \\
\text { antagonist }\end{array}$ & Vapiprost & & yes & yes & & & & \\
\hline 125 & $\begin{array}{l}\text { Unsaturated fatty } \\
\text { acid }\end{array}$ & $\begin{array}{l}\text { Hexadecatrienoic acid } \\
\text { [Hexadeca-2,4,6-trienoic } \\
\text { acid] }\end{array}$ & & & & & & & yes \\
\hline
\end{tabular}

\subsection{Similarities and Differences in Metabolites among the Lines}

According to Table 1 and Figure 3, the largest number of biologically active compounds (55) was found in lines S29 BLUE (4Th-4B) and S29 BLACK (4Th-4D), and the smallest (18) in the control line (differences of S29 from all the other lines are significant according to a two-sided test for proportions [Spearman's rank correlation analysis], $p=0.00001-0.0177$ ). Similar data were obtained for the polyphenol family: the largest (33 and 36) and smallest (12) numbers of such compounds were detected in the same lines as mentioned above. Phenolic compounds were found more often than nonphenolic compounds $(p=0.00001-0.0016)$ in all studied lines except for S29 BLUE (4Th-4D). In this line, the two classes of compounds showed almost equal numbers of members $(p=0.3428)$. Overall, in terms of the numbers of substances of a phenolic nature (53.3-70.3\% of the total number of identified compounds) and a nonphenolic nature (46.7-29.7\%) the studied lines were similar.

The results of cluster analysis of all the compounds (Figure 4) showed that two clusters can be distinguished in the dendrogram. The first cluster is formed by lines S29 BLACK (4Th-4B) and S29 BLUE (4Th-4D) and the adjacent S29 BLUE (4Th-4B) line. The second cluster consists of the control line S29 and of E22 BLACK (4Th-4D). Lines BW BLACK (4Th-4D) and S29 BLACK (4Th-4D) did not end up in any clusters. Analysis of Spearman's rank correlations confirmed the results of the cluster analysis. It was found that pairs of isogenic lines "S29 BLUE (4Th-4B)/S29 BLUE (4Th-4D)" and "S29 BLUE (4Th-4B)/S29 BLACK (4Th-4B)" (located in one cluster) are close to each other $\left(R_{S}=0.346-0.409, p<0.05\right)$. Similar results were obtained on the second cluster in the "S29/E22 BLACK (4Th-4D)" pair $\left(R_{\mathrm{S}}=0.333, p<0.05\right)$. In addition, statistically significant correlation coefficients $\left(R_{\mathrm{S}}=0.243-0.287, p<0.05\right)$ were obtained in the comparison of the pair of lines with a substituted 4D chromosome "S29 BLUE (4Th-4D)/E22 BLACK (4Th-4D)" and a pair of lines with the black seed color "S29 BLACK (4Th-4B)/E22 BLACK (4Th-4D)". 


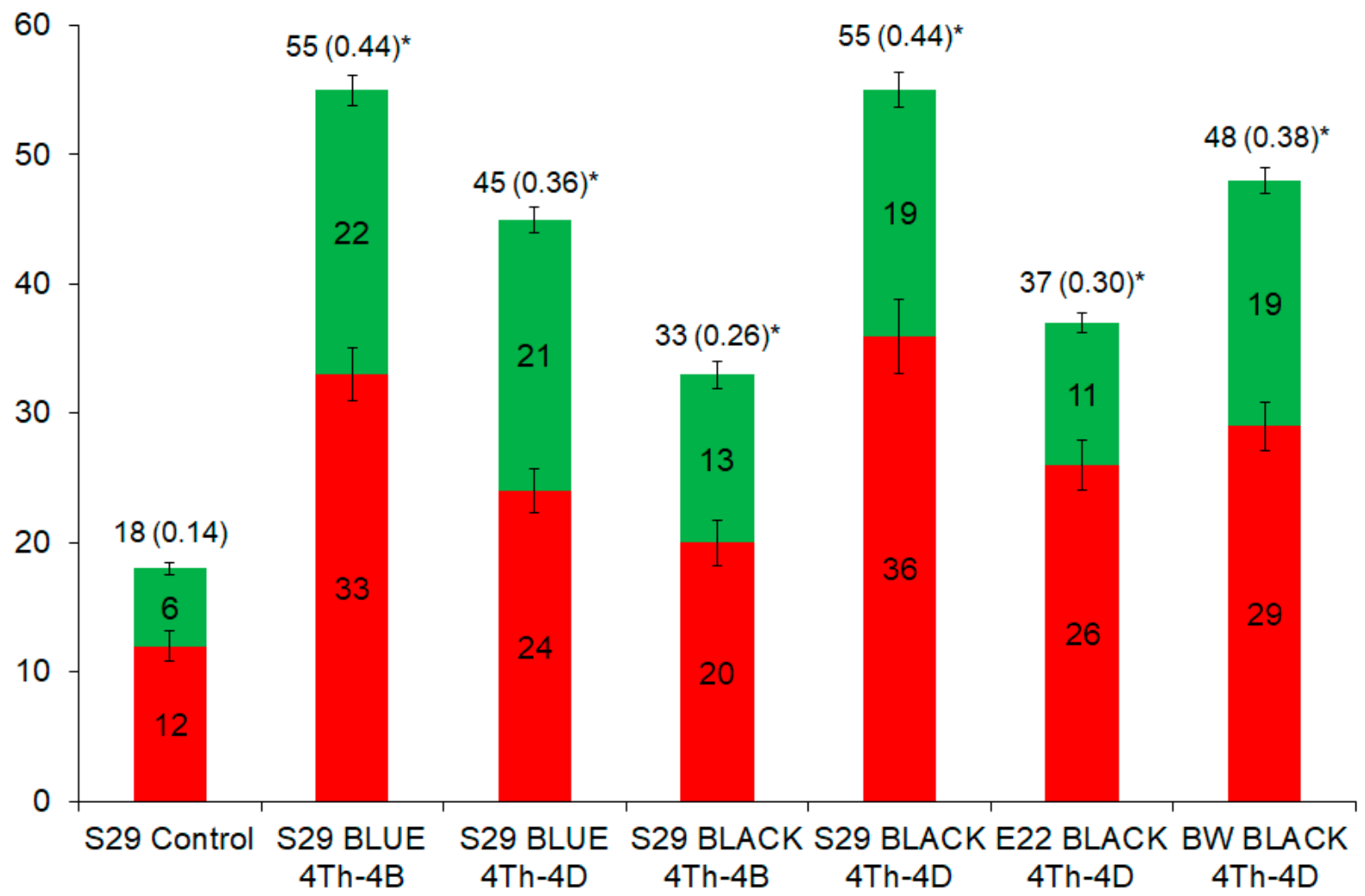

Figure 3. The number of the phenolic (red) and non-phenolic (green) compounds that were detected in the differently colored grains of the seven wheat lines. Error bars denote standard deviation; the number of individual compounds and its proportion among all the annotated compounds (125) are shown above the bars. * A significant difference from the control line.

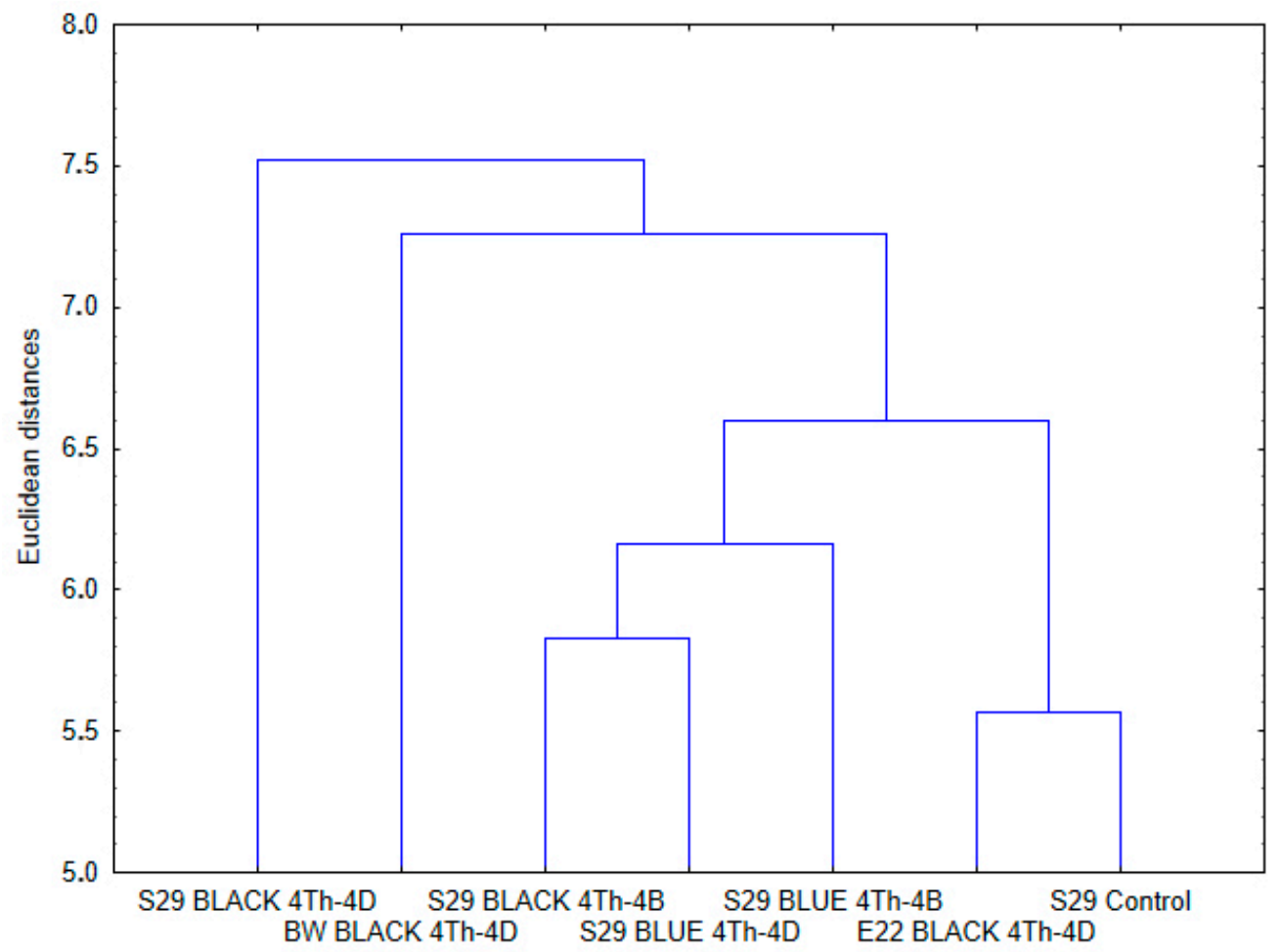

Figure 4. This tree was constructed by the unweighted pair group method with arithmetic mean (UPGMA) (based on Euclidean distances) from the data on 125 phenolic and nonphenolic substances of the seven T. aestivum lines. 
Plotting of dendrograms separately for phenolic and nonphenolic families of substances indicated that nonphenolic compounds differentiate lines by grain color (Figure S1). Even clearer separation by grain color was noted when the lignin family of compounds was utilized for the tree construction. Similar data were obtained on anthocyanins, flavones, and terpenoids. Unambiguous separation by substituted chromosomes was not achieved by means of any one family of substances. In some cases (e.g., for sterols and flavonols), one cluster was distinguished on the basis of the seed color, and the other cluster on the basis of chromosome substitution (Figure S1).

Examination of the chemical composition of wheat grains by the families of compounds within the phenolic and nonphenolic classes revealed that the lower number of biologically active substances detected in the control line can be explained by the absence of seven families of phenolic substances: coumarins, flavan-3-ols, flavanones, flavonols, phenolic acids, dihydrochalcone, and stilbenes. Flavonols were found in all the lines except for the control (S29). Furthermore, in S29, the number of substances belonging to the most numerous (in this study) "flavones" was 1.4-3.2-fold lower as compared to the other lines. The lower number of nonphenolic substances detected in the control line can be explained by the absence of the following families: alkaloids, anabolic steroids, carboxylic acids, carotenoids, cycloartanols, di- and triterpenoids, propionic acids, purines, sesquiterpenoid plant hormones, thromboxane receptor antagonists, and unsaturated fatty acids. Accordingly, the colored-grain lines showed a 3-6-fold greater number of substances in the carboxylic acid family, 2-3-fold in the sterol family, 2-4-fold in the anthocyanin family, and 1.5-2.7-fold in the flavone family as compared to the unpigmented-grain control (S29). It should also be noted that among the phenolic compounds, selgin (from the flavonol family) and abscisic acid [dormin; abscisin II; $(S)-(+)$-abscisic acid] from the class of nonphenolic compounds (sesquiterpenoid plant hormone family) were found only in lines with a substitution of chromosome 4B. A number of compounds (peonidin3-O-glucoside, caffeic acid derivative, apigenin, isorhamnetin, kaempferol, rhamnetin II, taxifolin-O-pentoside, salvianolic acid G, undecanedioic acid, cyclopassifloic acid glucoside, sespendole, berberine, and $\beta$-sitostenone) were found only in some lines with a substituted $4 \mathrm{D}$ chromosome (Table S1, 13 substances in total). In addition, some detected substances proved to be characteristic of only wheat with blue grains (malvidin 3-O-rutinoside-5-Oglucoside, petunidin 3-O-rutinoside-5-O-glucoside, apigenin $2^{\prime \prime}$-O-sinapoyl, $\mathrm{C}$-hexosyl, $C$-pentosyl, vicenin-2, isocryptotanshinone II, and vapiprost) or black grains (isorhamnetin and taxifolin-O-pentoside). The latter case includes only the lines with a substitution of chromosome 4D.

Among the 125 compounds identified in this study in wheat grains, 58 substances turned out to be unique, that is, each was detectable in only one of the seven analyzed lines. The lowest number of unique compounds (three and four) was found in lines S29 BLACK (4Th-4B) and S29, respectively, and the highest number (17 and 15) in S29 BLACK (4Th-4D) and BW BLACK (4Th-4D). The rest of the lines were somewhere in between. These data are in good agreement with the contribution of the unique compounds to the total pool of detected substances (Figure 5). It is worth mentioning that the difference between the proportions estimated by ratios-(1) the number of unique substances in a line to the sum of unique substances for all wheat lines under study and (2) the number of unique substances in a line to the total number of biologically active substances in this line-was 3.2-fold in the control line S29: the largest difference among the seven lines (Figure 5). In all the studied lines, the contribution of phenolic compounds to the pool of unique substances was predominant (60.0-88.2\%). 


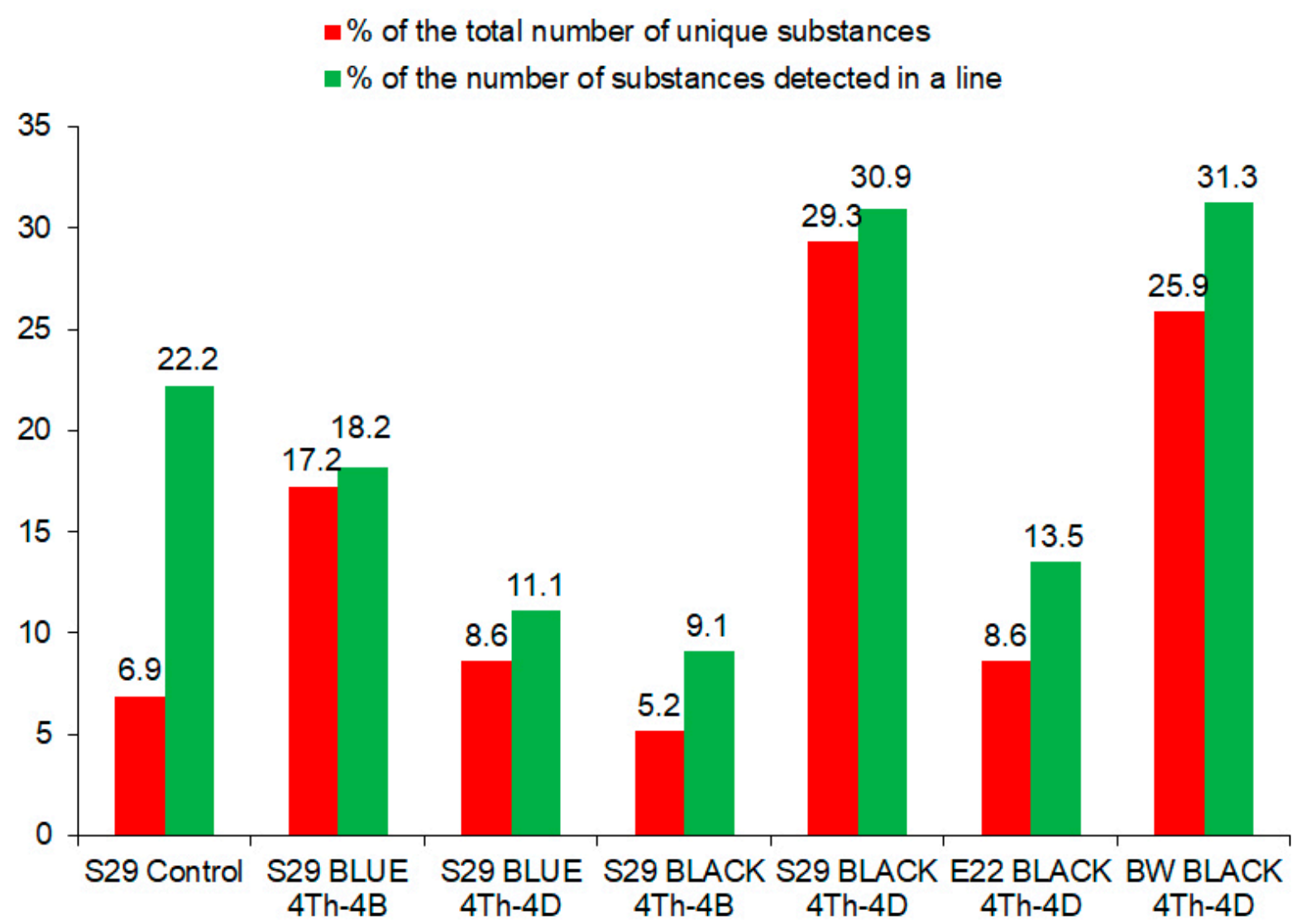

Figure 5. Assessment of the contributions of unique substances to the total pool of phenolic and nonphenolic compounds in the seven lines of T. aestivum.

Effects of various factors on the compounds' diversity in the seven lines were analyzed by one-way ANOVA on ranks (Table 2). It was found that factors "Chromosome Substitution", "Grain Color", and "Genotype of Line" affect the diversity of the chemical compounds, but "Genotype of Parental Line/Cultivar" does not. A multiple pairwise comparison of proportions of compounds (in the total number of compounds) in the groups of the lines having substituted chromosomes $4 \mathrm{~B}$ and $4 \mathrm{D}$ did not uncover any differences between the lines ( $p=0.688$, Duncan test). No such differences were revealed in the groups of lines with blue and black colors of grains ( $p=0.229$, Duncan test). Nonetheless, an effect of an interaction of two factors "Chromosome Substitution $\times$ Grain Color" on the diversity of compounds was detected (Figure 6A). In the group of the lines with substituted chromosome $4 \mathrm{D}$, there were no differences between the blue- and black-grained lines $(p=0.807$, Duncan test), whereas in the group of the lines with substituted chromosome $4 \mathrm{~B}$, such differences between the blue- and black-grained lines were found $(p=0.0023$, Duncan test), with significantly lower diversity of the compounds in the latter group. In the group of blue-grained lines, lower diversity of the compounds was observed in the lines with substituted chromosome 4D, while in the black-grained lines, the effect of chromosome substitutions was opposite: higher diversity (Figure 6B). 
Table 2. Effects of various factors on the diversity of phenolic and nonphenolic compounds in the seven wheat lines according to the Kruskal-Wallis $H$ test (i.e., one-way ANOVA on ranks; $d f$ : degrees of freedom).

\begin{tabular}{|c|c|c|c|c|c|c|c|c|}
\hline Factor & Group & $\begin{array}{l}\text { Group } \\
\text { Size }\end{array}$ & $d f$ & $\begin{array}{l}\text { Sum of } \\
\text { Ranks }\end{array}$ & $\begin{array}{l}\text { Mean } \\
\text { Rank }\end{array}$ & $\begin{array}{c}H \\
\text { Criterion }\end{array}$ & $p$ Value & $\begin{array}{l}\text { Significant } \\
\text { Result }\end{array}$ \\
\hline \multirow{3}{*}{$\begin{array}{l}\text { Chromosome } \\
\text { Substitution }\end{array}$} & 4Th-4B & 2 & \multirow{3}{*}{2} & $111,625.0$ & 446.5 & \multirow{3}{*}{23.58} & \multirow{3}{*}{0.00001} & \multirow{3}{*}{ yes } \\
\hline & $4 T h-4 \mathrm{D}$ & 4 & & $227,187.5$ & 454.4 & & & \\
\hline & Control & 1 & & $44,437.5$ & 355.5 & & & \\
\hline \multirow{3}{*}{$\begin{array}{l}\text { Genotype of } \\
\text { Parental } \\
\text { Line/Cultivar }\end{array}$} & BW & 1 & \multirow{3}{*}{2} & $57,562.5$ & 460.5 & \multirow{3}{*}{2.26} & \multirow{3}{*}{0.322} & \multirow{3}{*}{ no } \\
\hline & E22 & 1 & & $52,750.0$ & 422.0 & & & \\
\hline & S29 & 5 & & $272,937.5$ & 436.7 & & & \\
\hline \multirow{3}{*}{ Grain Color } & Black grains & 4 & \multirow{3}{*}{2} & 443.8750 & 443.8 & \multirow{3}{*}{25.52} & \multirow{3}{*}{0.00001} & \multirow{3}{*}{ yes } \\
\hline & Blue grains & 2 & & $116,875.0$ & 467.5 & & & \\
\hline & Control & 1 & & $44,437.5$ & 355.5 & & & \\
\hline \multirow{7}{*}{ Genotype of Line } & S29 BLUE (4Th-4B) & 1 & \multirow{7}{*}{6} & $60,625.0$ & 485.0 & \multirow{7}{*}{38.29} & \multirow{7}{*}{0.00001} & \multirow{7}{*}{ yes } \\
\hline & S29 BLUE (4Th-4D) & 1 & & $56,250.0$ & 450.0 & & & \\
\hline & S29 BLACK (4Th-4B) & 1 & & $51,000.0$ & 408.0 & & & \\
\hline & S29 BLACK (4Th-4D) & 1 & & $60,625.0$ & 485.0 & & & \\
\hline & E22 BLACK (4Th-4D) & 1 & & $57,562.5$ & 460.5 & & & \\
\hline & BW BLACK (4Th-4D) & 1 & & $52,750.0$ & 422.0 & & & \\
\hline & Control & 1 & & $44,437.5$ & 355.5 & & & \\
\hline
\end{tabular}

Current effect: $F(1,870)=6.25, p=0.0126$

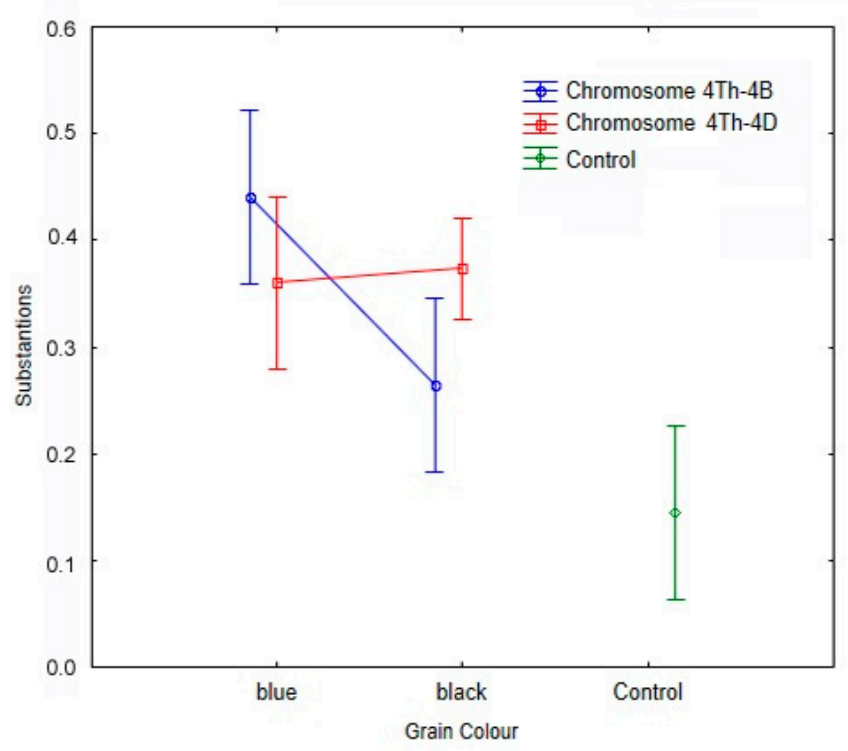

(A)

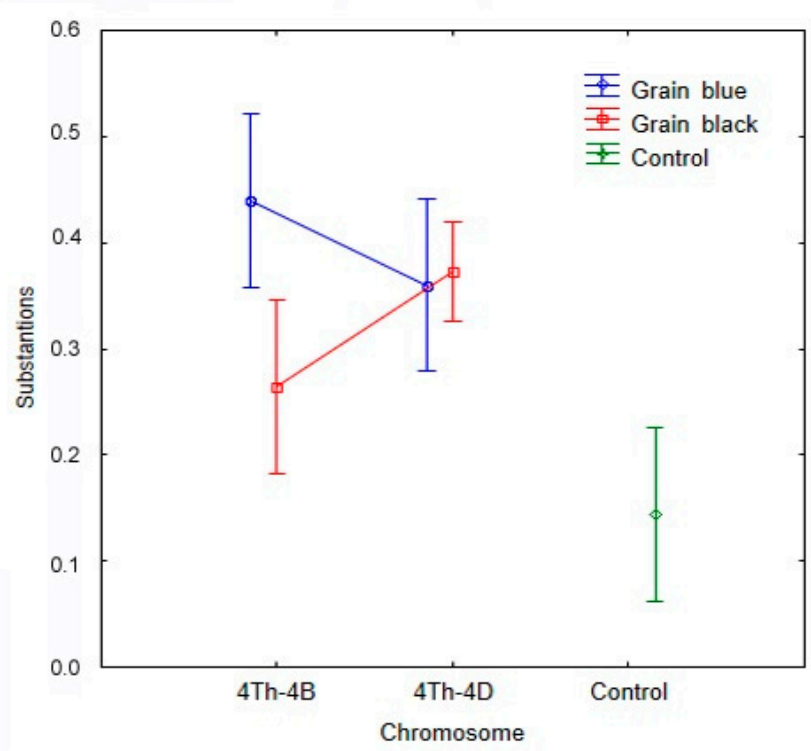

(B)

Figure 6. Effects of the factors "Chromosome Substitution" and "Grain Color" on diversity of chemicals in wheat grain assessed in groups of lines combined based on grain color (A) and substituted chromosomes (B), respectively, according to two-way ANOVA (Fisher's F test). Vertical bars denote 0.95 confidence intervals.

\section{Discussion}

Successful extraction of polyphenolic compounds depends on two sequential actions: dissolution of each polyphenolic compound at the cellular level in the matrix of plant material and its diffusion into the external medium (the solvent). This is why it is difficult to develop an extraction procedure suitable for all phenolic compounds. For the extraction of phenolic compounds, various organic solvents are commonly used, such as methanol, ethanol, acetone, ethyl acetate, or combinations thereof, often with different proportions of water. Additionally, an important factor directly affecting the solubility and extraction of 
these compounds is $\mathrm{pH}$ of the extraction medium, which determines the solubility of the soluble compounds and affects the possible solubilization of the hydrolyzable fraction.

Liquid chromatography is a versatile and well-established separation technique often employed for a variety of analytical tasks and allowing the separation of fairly complex mixtures of low- and high-molecular-weight compounds. This method is also suitable for different polarities and acid-base properties of various matrices.

In this study, 125 biologically active compounds of a phenolic and nonphenolic nature were identified in differently pigmented wheat grains by HPLC coupled with Bruker Daltonics ion trap MS/MS (Table 1). Our annotation results are consistent with the extensive mass-spectrometric literature data on the wheat T. aestivum [27-33] and other plant matrices, e.g., Passiflora incarnate [34], Bituminaria [35], Phyllostachys nigra [36], Carpobrotus edulis [37], and Vaccinium macrocarpon [38]. For example, the collision-induced dissociation spectrum (in negative ion mode) of a flavone called apigenin $2^{\prime \prime}$-O-sinapoyl, C-hexosyl, $C$-pentosyl from extracts of T. aestivum grains [line S29 BLUE (4Th-4D)] is given in Figure 7. The $[\mathrm{M}-\mathrm{H}]^{-}$molecular ion gave rise to three molecular ions at $m / z 545.02,724.18$, and 425.07 (see Figure 7). The molecular ion with $m / z 545.02$ yielded one daughter ion at $\mathrm{m} / \mathrm{z}$ 425.07. The molecular ion with $\mathrm{m} / \mathrm{z} 425.07$ broke up into three daughter ions with $m / z 365.00,335.04$, and 185.04. It was identified in the literature about extracts from $T$. aestivum [29].

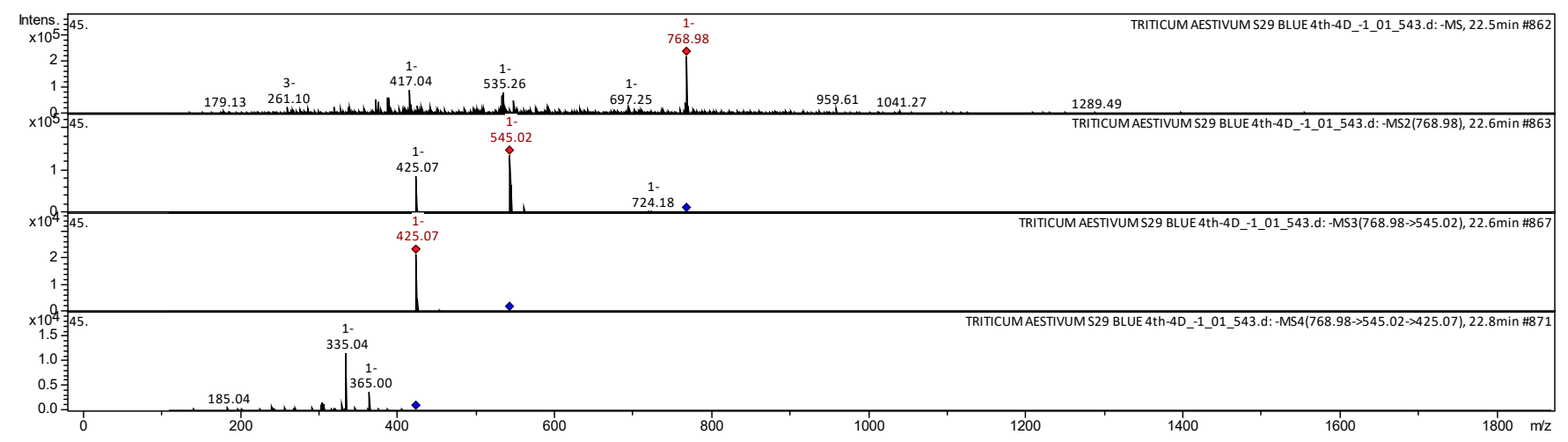

Figure 7. A collision-induced dissociation spectrum of apigenin $2^{\prime \prime}$-O-sinapoyl, C-hexosyl, C-pentosyl from extracts of $T$. aestivum grains, $m / z 768.98$.

Among the identified compounds, 87 were identified in wheat grains for the first time; they are affiliated with such phenolic compounds families as anthocyanins, coumarins, dihydrochalcones, flavan-3-ols, flavanone, flavones, flavonols, hydroxybenzoic acids, hydroxycinnamic acids, isoflavone, lignans, other phenolic acids, stilbenes, and nonphenolic compounds families as alkaloids, carboxylic acids, carotenoids, diterpenoids, essential amino acids, triterpenoids, sterols, nonessential amino acids, phytohormones, purines, and thromboxane receptor.

The diversity of phytochemicals may underlie diverse biological activities of the raw material. For instance, under the common name anthocyanins, there are up to 600 individual chemicals [39]. Biological activity of some individual anthocyanins has been tested, and distinct effects on physiological processes in animals and humans (or a lack of any) have been described. Antioxidant activity of anthocyanins is reported to be dependent on structural features of the molecules such as the number of hydroxyl and methyl groups and patterns of glycosylation [40]. Among anthocyanins, the highest antioxidant activity is featured by derivatives of delphinidin and cyanidin, followed by derivatives of malvidin, peonidin, pelargonidin, and petunidin [41]. In addition, a glycoside and rutinoside of cyanidin accelerate the regeneration of rhodopsin, while the derivatives of delphinidin have no effect [42]. Anthocyanidins have been demonstrated to be better inhibitors of cell proliferation than anthocyanins [43], with delphinidin and cyanidin having the best growth-inhibitory property and pelargonidin and malvidin devoid of such effects [44,45]. 
From these observations, we may conclude that the more compounds are present in plant material, the wider is the expected spectrum of biological activities. Investigation of such diversity is a promising field for the development of functional food programs and for pharmacological research.

Here, we compared the diversity of compounds among colored-grain wheat lines and observed that the anthocyaninless line S29 is characterized by the lowest diversity of all the identified compounds, phenolic compounds in particular (Figure 3). The lower diversity of biologically active compounds in S29 is explained by the absence of seven families of phenolics (coumarins, flavan-3-ols, flavanones, flavonols, phenolic acids, dihydrochalcones, and stilbenes) and 12 families of nonphenolic compounds (alkaloids, anabolic steroids, carboxylic acids, carotenoids, cycloartanols, di- and triterpenoids, propionic acids, purines, sesquiterpenoid plant hormones, thromboxane receptor antagonists, and unsaturated fatty acids). These data imply that the genes of wheatgrass chromosome 4Th and chromosome fragments introgressed into 2A and 7D (including the genes regulating anthocyanin biosynthesis) are responsible for the presence of the above compounds in the grain and thus affect the diversity of biologically active substances in the wheat grain.

Although the black-grained lines contain $P p$ genes in addition to $B a$ and one may expect an increased number of biologically active compounds in these lines, there were no significant differences in the number of identified compounds between blue- and black-grained lines having chromosome $4 \mathrm{D}$ substituted by $4 \mathrm{Th}$; moreover, a statistically significant decrease in the diversity of compounds was observed in the black-grained lines in comparison with the blue-grained lines having a chromosome $4 \mathrm{~B}$ substitution. According to the results of our one-way ANOVA on ranks, the diversity of the chemicals is affected by such genetic factors as "Chromosome Substitution," "Grain Color," and "Genotype of Line," but not "Genotype of Parental Line/Cultivar." (Table 2) In support of these data, some differences in the chemical profile were noted among the lines with distinct substitutions of chromosomes and among lines with different colors of grains (Table S1). For example, two compounds belonging to the classes of phenolic and nonphenolic substances-selgin and a sesquiterpenoid plant hormone, respectively-were identified only in the lines with substituted chromosome 4B [S29 BLUE (4Th-4B) and S29 BLACK (4Th-4B)]. This observation suggests that this chromosome carries regulatory factors suppressing the synthesis of these compounds. Removing them by substitution of the chromosomes carrying these repressors activates the synthesis of the compounds in the substitution lines. Some common features can be found among the chemical profiles of the lines with similar chromosomes composition. Even though the sister lines of S29 are genetically related (and there is a line based on E22 that has S29 in its pedigree [46]; Figure S2), some line-specific (unique) compounds were identified (Table 1, Figure 5). They constitute unique chemical fingerprints of each line, allowing to distinguish each line from the six others. The unique compounds of each line are hardly explained by the genetic relationships among the lines but can be considered the main reason for the separation of the analyzed lines into two subclusters observed in the dendrogram and the separation of lines S29 BLACK (4Th-4D) and BW BLACK (4Th-4D), which are characterized by the highest percentage of unique compounds (Figures 4 and 5).

\section{Materials and Methods}

\subsection{Materials}

The chemical profiles were analyzed in seven wheat lines with different grain colors and characterized genetic pedigrees (Table 3, Figure S2). The control group of (anthocyaninless) grains consisted of $c v$. Saratovskaya 29 (S29). Blue grains were represented by two wheat-wheatgrass substitution lines S29 BLUE(4Th-4B) and S29 BLUE (4Th-4D) developed in the S29 background but carrying $B a$ gene-containing wheatgrass chromosome $4 \mathrm{Th}$, which replaced wheat chromosomes $4 \mathrm{~B}$ and $4 \mathrm{D}$, respectively $[25,26]$. Black grains were represented by four lines, two of them-S29 BLACK (4Th-4B) and S29 BLACK (4Th-4D)-have been developed previously in the S29 background by crossing the above-mentioned lines 
with purple-grained near-isogenic wheat line S29 PURPLE $P p$-D1Pp3 carrying introgressions in chromosomes 7D and 2A, onto which the dominant alleles of genes $P p$-D1 and $P p 3$, respectively, have been mapped $[47,48]$. Two other black-grained lines-E22 BLACK $(4 T h-$ $4 \mathrm{D})$ and BW BLACK (4Th-4D) - were developed in the current study by marker-assisted transfer of genes $P p-D 1+P p 3$ and $B a$ from donor lines [S29 PURPLE $P p-D 1 P p 3$ and S29 BLUE (4Th-4D), respectively] into cv. Element 22 (E22) (P.A. Stolypin Omsk State Agrarian University, Omsk, Russia) and breeding line BW49880 (CIMMYT, INT, México-Veracruz, Mexico) (Figure S2).

Table 3. Genetic characteristics of the wheat lines used in this study.

\begin{tabular}{|c|c|c|c|c|c|c|}
\hline Genotype & Recurrent Parent & Grain Color & $B a$ & $P p-D 1+P p 3$ & $\begin{array}{l}\text { Substituted } \\
\text { Chromosome }\end{array}$ & References \\
\hline S29 BLUE(4Th-4D) & S29 & blue & + & - & $4 \mathrm{D}$ & [25] \\
\hline S29 BLUE(4Th-4B) & S29 & blue & + & - & $4 \mathrm{~B}$ & \multirow{3}{*}{ [26] } \\
\hline S29 BLACK(4Th-4B) & S29 & black & + & + & 4B & \\
\hline S29 BLACK(4Th-4D) & S29 & black & + & + & $4 \mathrm{D}$ & \\
\hline BW BLACK(4Th-4D) & BW49880 & black & + & + & $4 \mathrm{D}$ & \multirow{2}{*}{ Figure S2 } \\
\hline E22 BLACK(4Th-4D) & Element 22 & black & + & + & $4 \mathrm{D}$ & \\
\hline
\end{tabular}

\subsection{Chemicals and Reagents}

HPLC grade acetonitrile was purchased from Fisher Scientific (Southborough, UK), and MS grade formic acid from Sigma-Aldrich (Steinheim, Germany). Ultra-pure water was prepared by means of a SIEMENS ULTRA clear (SIEMENS Water Technologies, Munich, Germany), and all other chemicals were of analytical grade.

\subsection{Fractional Maceration}

To obtain highly concentrated extracts, fractional maceration was employed. In this technique, the total amount of an extractant (reagent grade ethyl alcohol) is divided into three parts and is sequentially applied to grains (first, the first part, then with the second and third). The infusion time for each part of the extractant was 14 days.

\subsection{Liquid Chromatography}

HPLC was performed on a Shimadzu LC-20 Prominence HPLC system (Shimadzu, Tokyo, Japan) equipped with a UV sensor and a Shodex ODP-40 4E reverse-phase column for the separation of multicomponent mixtures. The gradient elution program was as follows: from time point $0.01 \mathrm{~min}$ to $4.00 \mathrm{~min}, 100 \% \mathrm{~A}$; from 4 to $60 \mathrm{~min}, 100-25 \% \mathrm{~A}$; from 60 to $75 \mathrm{~min}, 25-0 \% \mathrm{~A}$; then, a control wash from 75 to $120 \mathrm{~min}$ at $0 \% \mathrm{~A}$. The entire HPLC analysis was carried out with an ESI detector at wavelengths of 230 and $330 \mathrm{~nm}$; the temperature was set to $17^{\circ} \mathrm{C}$, and the injection volume was $1 \mathrm{~mL}$.

\subsection{MS}

This analysis was performed on an ion trap amaZon SL instrument (Bruker Daltonics, Bremen, Germany) equipped with an electrospray ionization source, in negative ion mode. The following optimal parameters were found and applied: ionization source temperature $70{ }^{\circ} \mathrm{C}$, gas flow $4 \mathrm{~L} / \mathrm{min}$, nebulizer gas (atomizer) 7.3 psi, capillary voltage $4500 \mathrm{~V}$, end plate bend voltage $1500 \mathrm{~V}$, fragmentation voltage $280 \mathrm{~V}$, and collision energy $60 \mathrm{eV}$. The ion trap was used in the scan range $m / z$ 100-1700 for MS and MS/MS. The capture rate was 1 spectrum/s for MS and 3 spectra/s for MS/MS. Data collection was controlled by Hystar Data Analysis 4.1 software (Bruker Daltonics, Bremen, Germany). All the measurements were performed in triplicate. The combination of both ionization modes (positive and negative) in MS full scan mode provided extra confidence of the molecular mass determination. A comprehensive table of molecular masses of the target analytes 
isolated from the $\mathrm{EtOH}$ extracts of T. aestivum grains was compiled by comparing the $\mathrm{m} / \mathrm{z}$ values, retention times, and the fragmentation patterns with the MS/MS spectral data from the literature [28,29,31,34,49-57], and other sources or from searches of databases (MS2T, MassBank, and HMDB).

\subsection{Data Analysis}

A nonparametric test (Spearman's rank correlation analysis) was performed to compare the wheat lines having different grain colors; for estimation of differences between two groups, we used the two-sided version of the test. We also carried out the Kruskal-Wallis $H$ test (one-way ANOVA on ranks), the Fisher $F$ test (two-way ANOVA), and multiple pairwise analysis (Duncan test) in the STATISTICA 10.0 software [58]. To visualize the obtained data, a dendrogram based on Euclidean distances was drawn by the UPGMA.

\section{Conclusions}

As shown by a number of pharmacological studies, single-component drugs cannot be sufficiently effective in the treatment of multifactorial diseases. The mixtures of biologically active compounds that possess an ability to interact with each other often turn out to be more effective against a disease as compared to individual components of the mixture. Bioactive natural products containing a wide variety of compounds are considered more attractive for the production of functional foods and pharmacological research than formulations containing only a few components. Currently, the search for raw materials with a wide variety of biologically active compounds is an urgent task. In the present study, diversity of such compounds was investigated in anthocyanin-rich wheat grains by HPLC-MS/MS. Aside from anthocyanin, the study was focused on identifying other families of compounds of a phenolic and nonphenolic nature. A total of 125 biologically active compounds were identified, and among them, 87 were found in wheat grains for the first time. Statistically significantly higher diversity of the compounds was noted in colored grains of wheat in comparison with a control line, whereas between blue- and black-grained groups of lines, no differences were found. The unique chemical profiles with line-specific compounds were determined for each anthocyanin-rich line. The results make these lines promising sources of functional-food ingredients with a wide spectrum of biological activities.

Supplementary Materials: The following are available online, Figure S1: Dendrograms for seven T. aestivum lines. The trees were built using the UPGMA and Euclidean distance from data on different groups of chemicals, Figure S2: The breeding scheme for the development of the blue- and black-grained wheat lines used in this study, Table S1: The presence of biologically active compounds in the wheat lines grouped by chromosome substitution, grain color, or both.

Author Contributions: Conceptualization, E.K.K., M.P.R. and K.S.G.; methodology, M.P.R.; resources, E.K.K., A.M.Z., E.I.G. and K.S.G.; metabolome investigation and interpretation, M.P.R. and K.S.P.; metabolomic assay supervision, K.S.G.; metabolomic assay assistance, L.A.K.; data analysis and interpretation of genotype contributions, O.Y.S. and E.V.A.; writing-original draft preparation, M.P.R.; writing-review and editing, E.K.K., A.M.Z., O.Y.S., E.V.A. and K.S.G. All authors have read and agreed to the published version of the manuscript.

Funding: This research was funded by the Russian Science Foundation, grant number 21-66-00012. Wheat lines for chemical analysis of grain were propagated using resources of the Greenhouse Core Facility supported by ICG, project number 0259-2021-0012.

Institutional Review Board Statement: Not applicable.

Informed Consent Statement: Not applicable.

Data Availability Statement: The data presented in this study are available on request from the corresponding authors.

Acknowledgments: We thank Nikolai Shevchuk for linguistic advices and proofreading of the manuscript. 
Conflicts of Interest: The authors declare no conflict of interest.

\section{Appendix A}

Table A1. The list of compounds identified in EtOH extracts of T. aestivum grains.

\begin{tabular}{|c|c|c|c|c|c|c|c|}
\hline \multirow{2}{*}{ ID } & \multirow{2}{*}{ Identified Compound } & \multirow{2}{*}{$\begin{array}{l}\text { Molecular } \\
\text { Formula }\end{array}$} & \multirow{2}{*}{$\begin{array}{l}\text { Calculated } \\
\text { Mass }\end{array}$} & \multicolumn{2}{|c|}{ Observed Mass } & \multirow{2}{*}{$\begin{array}{c}\text { Fragment Ions, } \\
\mathrm{m} / \mathrm{z}\end{array}$} & \multirow{2}{*}{ References } \\
\hline & & & & {$[\mathbf{M}-\mathbf{H}]^{-}$} & {$[\mathbf{M}+\mathbf{H}]^{+}$} & & \\
\hline \multicolumn{8}{|c|}{ Anthocyanin } \\
\hline 1 & $\begin{array}{c}\text { Cyanidin } \\
\left.\text { 3-(2" }{ }^{\prime \prime} \text {-galloylglucoside }\right)\end{array}$ & $\mathrm{C}_{28} \mathrm{H}_{25} \mathrm{O}_{15+}$ & 601.4891 & & 602 & $\begin{array}{l}592 ; 556 ; 429 \\
349 ; 287 ; 231\end{array}$ & [59] \\
\hline 2 & $\begin{array}{l}\text { Cyanidin-3-O-3" }{ }^{\prime \prime} 6^{\prime \prime}-O- \\
\text { Dimalonylglucoside }\end{array}$ & $\mathrm{C}_{27} \mathrm{H}_{25} \mathrm{O}_{17}$ & 621.4772 & & 622 & $\begin{array}{l}\text { 612,395, 328, } \\
287,221\end{array}$ & [31] \\
\hline 3 & $\begin{array}{c}\text { Cyanidin-3-O-glucoside } \\
\text { [Cyanidin } \\
\text { 3-O- } \beta \text {-D-Glucoside; } \\
\text { Kuromarin] }\end{array}$ & $\mathrm{C}_{21} \mathrm{H}_{21} \mathrm{O}_{11}+$ & 449.3848 & & 450 & $\begin{array}{l}287 ; 213 ; 169 ; \\
115\end{array}$ & {$[31,54,60]$} \\
\hline 4 & Malvidin 3-O-rutinoside & $\mathrm{C}_{29} \mathrm{H}_{35} \mathrm{O}_{16}$ & 639.5786 & & 640 & $493 ; 331 ; 315$ & {$[31,61]$} \\
\hline 5 & $\begin{array}{l}\text { Malvidin 3-O-rutinoside- } \\
\text { 5-O-glucoside }\end{array}$ & $\mathrm{C}_{35} \mathrm{H}_{45} \mathrm{O}_{21}$ & 801.7192 & & 802 & $639 ; 493 ; 331$ & {$[31,61]$} \\
\hline 6 & Peonidin 3-O-rutinoside & $\mathrm{C}_{28} \mathrm{H}_{33} \mathrm{O}_{15}$ & 609.5526 & & 610 & $\begin{array}{l}463 ; 343 ; 301 ; \\
285 ; 258\end{array}$ & {$[31,59,62]$} \\
\hline 7 & $\begin{array}{c}\text { Peonidin } \\
\text { 3-rutinoside-5-glucoside }\end{array}$ & $\mathrm{C}_{34} \mathrm{H}_{43} \mathrm{O}_{20}$ & 771.6932 & & 772 & $\begin{array}{l}705 ; 463 ; 367 ; \\
301\end{array}$ & [31] \\
\hline 8 & Peonidin-3-O-glucoside & $\mathrm{C}_{22} \mathrm{H}_{23} \mathrm{O}_{11+}$ & 463.4114 & & 464 & $\begin{array}{l}301 ; 445 ; 286 ; \\
258\end{array}$ & {$[31,59,63]$} \\
\hline 9 & Petunidin & $\mathrm{C}_{16} \mathrm{H}_{13} \mathrm{O}_{7}$ & 317.2702 & & 318 & $\begin{array}{c}300 ; 256 ; 238 \\
198\end{array}$ & {$[31,61]$} \\
\hline 10 & $\begin{array}{c}\text { Petunidin 3-O-rutinoside- } \\
\text { 5-O-glucoside }\end{array}$ & $\mathrm{C}_{34} \mathrm{H}_{43} \mathrm{O}_{21}$ & 787.6926 & & 788 & $625 ; 479 ; 317$ & {$[31,61]$} \\
\hline \multicolumn{8}{|c|}{ Cinnamic Acid Derivative } \\
\hline 11 & Ferulic acid methyl ester & $\mathrm{C}_{11} \mathrm{H}_{12} \mathrm{O}_{4}$ & 208.2106 & 207 & & $179 ; 135$ & [64] \\
\hline \multicolumn{8}{|c|}{ Hydroxycinnamic Acid } \\
\hline 12 & $\begin{array}{l}\text { 1-Caffeoyl- } \beta \text {-D-glucose } \\
\text { [Caffeic acid-glucoside] }\end{array}$ & $\mathrm{C}_{15} \mathrm{H}_{18} \mathrm{O}_{9}$ & 342.298 & 341 & & $161 ; 143$ & {$[34,63]$} \\
\hline 13 & $\begin{array}{l}\text { 1-O-Sinapoyl- } \beta-\mathrm{D}- \\
\text { glucose }\end{array}$ & $\mathrm{C}_{17} \mathrm{H}_{22} \mathrm{O}_{10}$ & 386.3576 & & 387 & 205 & [63] \\
\hline 14 & Caffeic acid derivative & $\mathrm{C}_{16} \mathrm{H}_{18} \mathrm{O}_{9} \mathrm{Na}$ & 377.2985 & 377 & & $341 ; 178 ; 143$ & [65] \\
\hline 15 & $\begin{array}{c}\text { Caftaric acid [Cis-Caftaric } \\
\text { acid; } \\
\text { 2-Caffeoyl-L-Tartaric } \\
\text { acid] }\end{array}$ & $\mathrm{C}_{13} \mathrm{H}_{12} \mathrm{O}_{9}$ & 312.23 & 311 & & $\begin{array}{l}267 ; 293 ; 249 ; \\
193 ; 183 ; 167\end{array}$ & {$[37,49,63,66]$} \\
\hline 16 & $\begin{array}{c}\text { Chlorogenic acid } \\
\text { [3-O-Caffeoylquinic acid] }\end{array}$ & $\mathrm{C}_{16} \mathrm{H}_{18} \mathrm{O}_{9}$ & 354.3087 & & 355 & $\begin{array}{l}337 ; 319 ; 301 ; \\
239 ; 222 ; 227\end{array}$ & {$[54,67]$} \\
\hline 17 & Ferulic acid & $\mathrm{C}_{10} \mathrm{H}_{10} \mathrm{O}_{4}$ & 194.184 & & 195 & 137 & {$[54,68]$} \\
\hline \multicolumn{8}{|c|}{ Coumarin } \\
\hline 18 & Fraxetin & $\mathrm{C}_{10} \mathrm{H}_{8} \mathrm{O}_{5}$ & 208.1675 & 207 & & $\begin{array}{l}179 ; 161 ; 135 ; \\
117\end{array}$ & [69-71] \\
\hline 19 & Fraxetin-7-O-sulfate & $\mathrm{C}_{10} \mathrm{H}_{8} \mathrm{O}_{8} \mathrm{~S}$ & 288.2307 & 287 & & $207 ; 163 ; 119$ & [69] \\
\hline \multicolumn{8}{|c|}{ Dihydrochalcone } \\
\hline 20 & $\begin{array}{l}\text { Phlorizin [Phloridzin; } \\
\text { Phlorizoside; Floridzin; } \\
\text { Phloretin 2'-Glucoside] }\end{array}$ & $\mathrm{C}_{21} \mathrm{H}_{24} \mathrm{O}_{10}$ & 436.4093 & & 437 & $\begin{array}{l}275 ; 257 ; 203 \\
\quad 173 ; 150\end{array}$ & {$[37,53,55,72]$} \\
\hline
\end{tabular}


Table A1. Cont.

\begin{tabular}{|c|c|c|c|c|c|c|c|}
\hline \multirow{2}{*}{ ID } & \multirow{2}{*}{ Identified Compound } & \multirow{2}{*}{$\begin{array}{c}\text { Molecular } \\
\text { Formula }\end{array}$} & \multirow{2}{*}{$\begin{array}{l}\text { Calculated } \\
\text { Mass }\end{array}$} & \multicolumn{2}{|c|}{ Observed Mass } & \multirow{2}{*}{$\begin{array}{c}\text { Fragment Ions, } \\
m / z\end{array}$} & \multirow{2}{*}{ References } \\
\hline & & & & {$[\mathbf{M}-\mathbf{H}]^{-}$} & {$[\mathrm{M}+\mathrm{H}]^{+}$} & & \\
\hline & & & Flavan-3-ol & & & & \\
\hline 21 & Catechin [D-Catechol] & $\mathrm{C}_{15} \mathrm{H}_{14} \mathrm{O}_{6}$ & 290.2681 & & 291 & $245 ; 203 ; 145$ & $\begin{array}{c}{[53,55,56,66,68,} \\
73-76]\end{array}$ \\
\hline 22 & Epicatechin & $\mathrm{C}_{15} \mathrm{H}_{14} \mathrm{O}_{6}$ & 290.2681 & & 291 & $\begin{array}{c}273 ; 255 ; 213 ; \\
147 ; 127\end{array}$ & $\begin{array}{c}{[37,53,63,68,75-} \\
77]\end{array}$ \\
\hline \multirow[t]{2}{*}{23} & $\begin{array}{l}\text { Gallocatechin [+(-) } \\
\text { Gallocatechin] }\end{array}$ & $\mathrm{C}_{15} \mathrm{H}_{14} \mathrm{O}_{7}$ & 306.2675 & 305 & & $\begin{array}{l}287 ; 249 ; 205 ; \\
151 ; 138 ; 125\end{array}$ & {$[37,66,73]$} \\
\hline & & & Flavanone & & & & \\
\hline 24 & Naringenin [Naringetol] & $\mathrm{C}_{15} \mathrm{H}_{12} \mathrm{O}_{5}$ & 272.5228 & & 273 & $156 ; 191 ; 112$ & {$[53,57,63,73,78]$} \\
\hline \multicolumn{8}{|c|}{ Flavone } \\
\hline 25 & $\begin{array}{c}\text { 6-C-hexosyl-chrysoeriol } \\
\text { O-rhamnoside-O- } \\
\text { hexoside }\end{array}$ & $\mathrm{C}_{33} \mathrm{H}_{38} \mathrm{O}_{21}$ & 770.6422 & & 771 & $\begin{array}{c}753 ; 704 ; 687 ; \\
585 ; 529 ; 499 ; \\
427 ; 422 ; 385 ; \\
337 ; 207\end{array}$ & [27] \\
\hline 26 & $\begin{array}{l}\text { Acacetin } C \text {-glucoside } \\
\text { methylmalonylated }\end{array}$ & $\mathrm{C}_{26} \mathrm{H}_{26} \mathrm{O}_{13}$ & 546.4758 & & 547 & $\begin{array}{l}529 ; 511 ; 427 \\
301 ; 253 ; 172\end{array}$ & [79] \\
\hline 27 & Apigenin & $\mathrm{C}_{15} \mathrm{H}_{10} \mathrm{O}_{5}$ & 270.2369 & & 271 & $\begin{array}{l}252 ; 239 ; 226 ; \\
211\end{array}$ & [34] \\
\hline 28 & $\begin{array}{c}\text { Apigenin } 2^{\prime \prime} \text {-O-sinapoyl, } \\
\text { C-hexosyl, C-pentosyl }\end{array}$ & $\mathrm{C}_{37} \mathrm{H}_{38} \mathrm{O}_{18}$ & 770.6868 & 768 & & $\begin{array}{l}545 ; 425 ; 365 ; \\
\quad 335 ; 185\end{array}$ & [29] \\
\hline 29 & $\begin{array}{c}\text { Apigenin } \\
\text { 6,8-di-C-pentoside }\end{array}$ & $\mathrm{C}_{25} \mathrm{H}_{26} \mathrm{O}_{13}$ & 534.4661 & & 535 & $\begin{array}{l}499 ; 481 ; 415 \\
409 ; 307 ; 291\end{array}$ & {$[34,49,80]$} \\
\hline 30 & $\begin{array}{l}\text { Apigenin } \\
\text { 6- } C \text {-deoxyhexoside- } 8-C \text { - } \\
\text { pentoside }\end{array}$ & $\mathrm{C}_{26} \mathrm{H}_{28} \mathrm{O}_{13}$ & 548.4927 & & 549 & $\begin{array}{l}531 ; 465 ; 369 \\
319 ; 248\end{array}$ & [34] \\
\hline 31 & $\begin{array}{l}\text { Apigenin-6-C- } \beta- \\
\text { galactosyl-8-C- } \beta- \\
\text { glycosyl-O- } \\
\text { glycuronopyranoside }\end{array}$ & $\mathrm{C}_{33} \mathrm{H}_{38} \mathrm{O}_{21}$ & 770.6422 & & 771 & $\begin{array}{l}679 ; 651 ; 561 ; \\
511 ; 457 ; 367 ; \\
313 ; 297 ; 267 ; \\
249 ; 215 ; 207 ; \\
177 ; 121\end{array}$ & [28] \\
\hline 32 & $\begin{array}{c}\text { Apigenin 8-C-hexoside-6- } \\
\text { C-pentoside }\end{array}$ & $\mathrm{C}_{26} \mathrm{H}_{28} \mathrm{O}_{14}$ & 564.4921 & & 565 & $\begin{array}{l}547 ; 529 ; 511 ; \\
481 ; 427 ; 349 \\
\quad 325 ; 313\end{array}$ & {$[28,29,35]$} \\
\hline 33 & $\begin{array}{l}\text { Apigenin 8-C-pentoside- } \\
\text { 6-C-hexoside }\end{array}$ & $\mathrm{C}_{26} \mathrm{H}_{28} \mathrm{O}_{14}$ & 564.4921 & & 565 & $\begin{array}{l}\text { 547; 529; 511; } \\
427 ; 391 ; 325 ; \\
291 ;\end{array}$ & {$[28,29,35]$} \\
\hline 34 & Chrysoeriol & $\mathrm{C}_{16} \mathrm{H}_{12} \mathrm{O}_{6}$ & 300.2629 & & 301 & $286 ; 258 ; 229$ & {$[33,60,81]$} \\
\hline 35 & $\begin{array}{c}\text { Chrysoeriol } \\
\text { C-hexoside-C-pentoside }\end{array}$ & $\mathrm{C}_{27} \mathrm{H}_{30} \mathrm{O}_{15}$ & 594.5181 & & 595 & $\begin{array}{l}577 ; 558 ; 499 ; \\
481 ; 427 ; 379 ; \\
327 ; 287\end{array}$ & {$[27,29,32,35]$} \\
\hline 36 & Cirsiliol & $\mathrm{C}_{17} \mathrm{H}_{14} \mathrm{O}_{7}$ & 330.2889 & 329 & & $\begin{array}{l}229 ; 211 ; 171 ; \\
155\end{array}$ & [52] \\
\hline 37 & $\begin{array}{c}\text { Dihydroxy } \\
\text { tetramethoxyflavanone }\end{array}$ & $\mathrm{C}_{19} \mathrm{H}_{20} \mathrm{O}_{8}$ & 376.3573 & & 377 & $\begin{array}{l}361 ; 323 ; 265 \\
179\end{array}$ & [37] \\
\hline 38 & $\begin{array}{l}\text { Diosmetin [Luteolin } \\
4^{\prime} \text {-Methyl Ether; } \\
\text { Salinigricoflavonol] }\end{array}$ & $\mathrm{C}_{16} \mathrm{H}_{12} \mathrm{O}_{6}$ & 300.2629 & & 301 & $\begin{array}{c}286 ; 258 ; 177 \\
138\end{array}$ & [81-83] \\
\hline 39 & $\begin{array}{c}\text { Genistein } \\
\text { C-glucosylglucoside }\end{array}$ & $\mathrm{C}_{27} \mathrm{H}_{30} \mathrm{O}_{15}$ & 594.5181 & & 595 & $\begin{array}{l}577 ; 529 ; 457 \\
\quad 427 ; 302 \\
\end{array}$ & [79] \\
\hline 40 & $\begin{array}{c}\text { Hydroxy } \\
\text { dimethoxyflavone } \\
\text { hexoside }\end{array}$ & $\mathrm{C}_{23} \mathrm{H}_{24} \mathrm{O}_{10}$ & 460.4307 & & 461 & $\begin{array}{l}301 ; 286 ; 258 ; \\
243\end{array}$ & [37] \\
\hline 41 & Luteolin & $\mathrm{C}_{15} \mathrm{H}_{10} \mathrm{O}_{6}$ & 286.2363 & 285 & & 199; 151 & $\begin{array}{c}{[33,36,50,52,73,} \\
84]\end{array}$ \\
\hline
\end{tabular}


Table A1. Cont.

\begin{tabular}{|c|c|c|c|c|c|c|c|}
\hline \multirow{2}{*}{ ID } & \multirow{2}{*}{ Identified Compound } & \multirow{2}{*}{$\begin{array}{l}\text { Molecular } \\
\text { Formula }\end{array}$} & \multirow{2}{*}{$\begin{array}{l}\text { Calculated } \\
\text { Mass }\end{array}$} & \multicolumn{2}{|c|}{ Observed Mass } & \multirow{2}{*}{$\begin{array}{c}\text { Fragment Ions, } \\
\mathrm{m} / \mathrm{z}\end{array}$} & \multirow{2}{*}{ References } \\
\hline & & & & {$[\mathbf{M}-\mathbf{H}]^{-}$} & {$[\mathrm{M}+\mathrm{H}]^{+}$} & & \\
\hline 42 & $\begin{array}{l}\text { Luteolin 8-C-Glucoside } \\
\text { [Orientin; Orientin } \\
\text { (Flavone); Lutexin] }\end{array}$ & $\mathrm{C}_{21} \mathrm{H}_{20} \mathrm{O}_{11}$ & 448.3769 & & 449 & $\begin{array}{c}431 ; 413 ; 356 ; \\
333 ; 290 ; 267 ; \\
233 ; 227\end{array}$ & {$[28,36,49,55]$} \\
\hline 43 & $\begin{array}{l}\text { Luteolin 8-C-hexoside-6- } \\
\text { C-pentoside }\end{array}$ & $\mathrm{C}_{26} \mathrm{H}_{28} \mathrm{O}_{15}$ & 580.4915 & & 581 & $\begin{array}{l}563 ; 515 ; 485 ; \\
413 ; 377 ; 342 ; \\
205\end{array}$ & {$[27,29,32,35]$} \\
\hline 44 & $\begin{array}{c}\text { Luteolin 8-C-pentoside-6- } \\
\text { C-hexoside }\end{array}$ & $\mathrm{C}_{26} \mathrm{H}_{28} \mathrm{O}_{15}$ & 580.4915 & & 581 & $\begin{array}{l}563 ; 528 ; 515 ; \\
496 ; 443 ; 413 ; \\
341 ; 335 ; 323 ; \\
181\end{array}$ & {$[28,29,33]$} \\
\hline 45 & Myricetin & $\mathrm{C}_{15} \mathrm{H}_{10} \mathrm{O}_{8}$ & 318.2351 & 317 & & $273 ; 260 ; 238$ & {$[37,38,63,73,85]$} \\
\hline 46 & $\begin{array}{c}\text { Orientin } \\
\text { 7-O-deoxyhexoside } \\
\text { [Luteolin 8-C-glucoside } \\
\text { 7-O-deoxyhexoside] }\end{array}$ & $\mathrm{C}_{27} \mathrm{H}_{30} \mathrm{O}_{15}$ & 594.5181 & & 595 & $\begin{array}{l}577 ; 528 ; 510 ; \\
438 ; 427 ; 325\end{array}$ & [34] \\
\hline 47 & $\begin{array}{c}\text { Pentahydroxy } \\
\text { dimethoxyflavone }\end{array}$ & $\mathrm{C}_{17} \mathrm{H}_{14} \mathrm{O}_{9}$ & 362.2877 & & 363 & $\begin{array}{l}\text { 345; 326; } 247 \\
\text { 201; } 155\end{array}$ & [37] \\
\hline 48 & $\begin{array}{c}\text { Pentahydroxy } \\
\text { dimethoxyflavone } \\
\text { hexoside }\end{array}$ & $\mathrm{C}_{23} \mathrm{H}_{24} \mathrm{O}_{14}$ & 524.4283 & & 525 & $463 ; 363 ; 257$ & [37] \\
\hline 49 & $\begin{array}{l}\text { Pentahydroxy trimethoxy } \\
\text { flavone }\end{array}$ & $\mathrm{C}_{18} \mathrm{H}_{16} \mathrm{O}_{10}$ & 392.3136 & & 393 & $\begin{array}{l}375 ; 357 ; 328 ; \\
269 ; 230 ; 218\end{array}$ & [37] \\
\hline 50 & Tricin & $\mathrm{C}_{17} \mathrm{H}_{14} \mathrm{O}_{7}$ & 330.2889 & & 331 & $\begin{array}{l}315 ; 287 ; 285 \\
270 ; 229\end{array}$ & {$[28,33,36,54]$} \\
\hline 51 & $\begin{array}{c}\text { Tetrahydroxy- } \\
\text { dimethoxyflavone- } \\
\text { hexoside } \\
\text { [Syringetin-hexoside; } \\
\text { dimethyl-myricetin- } \\
\text { hexoside] }\end{array}$ & $\mathrm{C}_{23} \mathrm{H}_{24} \mathrm{O}_{13}$ & 508.4289 & & 509 & $\begin{array}{l}347 ; 329 ; 316 ; \\
265 ; 185 ; 181\end{array}$ & {$[38,49,80]$} \\
\hline 52 & $\begin{array}{c}\text { Trihydroxy } \\
\text { methoxyflavone } \\
\text { triacetate }\end{array}$ & $\mathrm{C}_{18} \mathrm{H}_{18} \mathrm{O}_{9}$ & 378.3301 & & 379 & $\begin{array}{l}361 ; 321 ; 287 \\
234 ; 223 ; 167\end{array}$ & [37] \\
\hline 53 & $\begin{array}{l}\text { Vicenin-2 [Apigenin-6,8- } \\
\text { Di-C-Glucoside] }\end{array}$ & $\mathrm{C}_{27} \mathrm{H}_{30} \mathrm{O}_{15}$ & 594.5181 & & 595 & $\begin{array}{l}577 ; 559 ; 541 ; \\
529 ; 523 ; 499 ; \\
469 ; 439 ; 427 ; \\
391\end{array}$ & $\begin{array}{c}{[28-} \\
30,34,35,50,55]\end{array}$ \\
\hline 54 & $\begin{array}{c}\text { Vitexin } 2^{\prime \prime}-O \text {-glucoside } \\
\text { [Apigenin 8-C-glucoside } \\
2^{\prime \prime} \text {-O-glucoside] }\end{array}$ & $\mathrm{C}_{27} \mathrm{H}_{30} \mathrm{O}_{15}$ & 594.5181 & & 595 & $\begin{array}{l}577 ; 541 ; 457 \\
288\end{array}$ & [34] \\
\hline 55 & $\begin{array}{c}\text { Vitexin } 6^{\prime \prime} \text {-O-glucoside } \\
\text { [Apigenin 8-C-glucoside } \\
6^{\prime \prime} \text {-O-glucoside] }\end{array}$ & $\mathrm{C}_{27} \mathrm{H}_{30} \mathrm{O}_{15}$ & 594.5181 & & 595 & $\begin{array}{l}577 ; 559 ; 528 ; \\
511 ; 499 ; 493 ; \\
487 ; 445 ; 427\end{array}$ & [34] \\
\hline 56 & Wighteone-O-glucoside & $\mathrm{C}_{26} \mathrm{H}_{28} \mathrm{O}_{10}$ & 500.4945 & & 501 & $\begin{array}{c}339 ; 262 ; 185 ; \\
167\end{array}$ & [79] \\
\hline
\end{tabular}


Table A1. Cont.

\begin{tabular}{|c|c|c|c|c|c|c|c|}
\hline \multirow{2}{*}{ ID } & \multirow{2}{*}{ Identified Compound } & \multirow{2}{*}{$\begin{array}{l}\text { Molecular } \\
\text { Formula }\end{array}$} & \multirow{2}{*}{$\begin{array}{l}\text { Calculated } \\
\text { Mass }\end{array}$} & \multicolumn{2}{|c|}{ Observed Mass } & \multirow{2}{*}{$\begin{array}{l}\text { Fragment Ions, } \\
\qquad m / z\end{array}$} & \multirow[b]{2}{*}{ References } \\
\hline & & & & {$[\mathbf{M}-\mathbf{H}]^{-}$} & {$[\mathbf{M}+\mathbf{H}]^{+}$} & & \\
\hline \multicolumn{8}{|c|}{ Flavonol } \\
\hline 57 & $\begin{array}{l}\text { Ampelopsin } \\
\text { [Dihydromyricetin; } \\
\text { Ampeloptin] }\end{array}$ & $\mathrm{C}_{15} \mathrm{H}_{12} \mathrm{O}_{8}$ & 320.251 & & 321 & $303 ; 285 ; 163$ & {$[86,87]$} \\
\hline 58 & $\begin{array}{c}\text { Isorhamnetin } \\
\text { [Isorhamnetol; Quercetin } \\
\text { 3'-Methyl ether; } \\
\text { 3-Methylquercetin] }\end{array}$ & $\mathrm{C}_{16} \mathrm{H}_{12} \mathrm{O}_{7}$ & 316.2623 & 315 & & $\begin{array}{c}300 ; 272 ; 243 ; \\
145\end{array}$ & {$[38,53]$} \\
\hline 59 & Kaempferide & $\mathrm{C}_{16} \mathrm{H}_{12} \mathrm{O}_{6}$ & 300.2629 & & 301 & $\begin{array}{l}286 ; 258 ; 229 \\
\text { 174; } 153\end{array}$ & {$[52,88]$} \\
\hline 60 & Kaempferol & $\mathrm{C}_{15} \mathrm{H}_{10} \mathrm{O}_{6}$ & 286.2363 & & 287 & $\begin{array}{l}268 ; 214 ; 196 \\
160 ; 123\end{array}$ & {$[52,63,73,89]$} \\
\hline 61 & Quercetin & $\mathrm{C}_{15} \mathrm{H}_{10} \mathrm{O}_{7}$ & 302.2357 & 301 & & $283 ; 255 ; 227$ & $\begin{array}{c}{[38,53,54,57,63,} \\
68,73,76]\end{array}$ \\
\hline 62 & $\begin{array}{c}\text { Rhamnetin I } \\
\text { [ } \beta \text {-Rhamnocitrin; } \\
\text { Quercetin 7-Methyl ether] }\end{array}$ & $\mathrm{C}_{16} \mathrm{H}_{12} \mathrm{O}_{7}$ & 316.2623 & & 317 & $\begin{array}{l}255 ; 197 ; 139 ; \\
122\end{array}$ & [86] \\
\hline 63 & Rhamnetin II & $\mathrm{C}_{16} \mathrm{H}_{12} \mathrm{O}_{7}$ & 316.2623 & & 317 & $\begin{array}{c}256 ; 121 ; 228 ; \\
111\end{array}$ & [86] \\
\hline 64 & $\begin{array}{c}\text { Selgin [Selagin; } \\
\text { 3'-O-Methyltricetin; } \\
\text { Tricetin'3-O-methyl } \\
\text { ether] }\end{array}$ & $\mathrm{C}_{16} \mathrm{H}_{12} \mathrm{O}_{7}$ & 316.2623 & & 317 & $315 ; 256 ; 161$ & [90] \\
\hline 65 & Taxifolin-3-O-glucoside & $\mathrm{C}_{21} \mathrm{H}_{22} \mathrm{O}_{12}$ & 466.3922 & & 467 & $\begin{array}{c}449 ; 373 ; 258 \\
199 ; 177\end{array}$ & [63] \\
\hline 66 & $\begin{array}{l}\text { Taxifolin-O-pentoside } \\
\text { [Dihydroquercetin } \\
\text { pentoside] }\end{array}$ & $\mathrm{C}_{20} \mathrm{H}_{20} \mathrm{O}_{11}$ & 436.371 & & 437 & $\begin{array}{l}303 ; 259 ; 177 \\
169\end{array}$ & [37] \\
\hline \multicolumn{8}{|c|}{ Gallotannin } \\
\hline 67 & $\begin{array}{l}\beta \text {-Glucogallin [1-O- } \\
\text { Galloyl- } \beta \text {-D-Glucose; } \\
\text { Galloyl glucose] }\end{array}$ & $\mathrm{C}_{13} \mathrm{H}_{16} \mathrm{O}_{10}$ & 332.2601 & 331 & & $\begin{array}{l}313 ; 295 ; 277 \\
171 ; 140 ; 127\end{array}$ & {$[53,91]$} \\
\hline \multicolumn{8}{|c|}{ Hydroxybenzoic Acid } \\
\hline 68 & $\begin{array}{l}\text { 4-Hydroxybenzoic acid } \\
\text { [PHBA; Benzoic acid] }\end{array}$ & $\mathrm{C}_{7} \mathrm{H}_{6} \mathrm{O}_{3}$ & 138.1207 & & 139 & $137 ; 121$ & {$[35,49,63,74]$} \\
\hline 69 & Cis-salvianolic acid J & $\mathrm{C}_{27} \mathrm{H}_{22} \mathrm{O}_{12}$ & 538.4564 & & 539 & $\begin{array}{l}523 ; 481 ; 393 ; \\
360 ; 319 ; 247 ; \\
204 ; 191 ; 120\end{array}$ & [81] \\
\hline 70 & $\begin{array}{l}\text { Hydroxy methoxy } \\
\text { dimethylbenzoic acid }\end{array}$ & $\mathrm{C}_{10} \mathrm{H}_{12} \mathrm{O}_{4}$ & 196.1999 & & 197 & 179; 160; 133 & [37] \\
\hline 71 & Salvianolic acid D & $\mathrm{C}_{20} \mathrm{H}_{18} \mathrm{O}_{10}$ & 418.3509 & 417 & & $373 ; 329 ; 287$ & {$[49,92]$} \\
\hline 72 & Salvianolic acid F & $\mathrm{C}_{17} \mathrm{H}_{14} \mathrm{O}_{6}$ & 314.2895 & 313 & & $\begin{array}{l}295 ; 277 ; 223 ; \\
171 ; 155\end{array}$ & {$[49,92]$} \\
\hline 73 & Salvianolic acid G & $\mathrm{C}_{18} \mathrm{H}_{12} \mathrm{O}_{7}$ & 340.2837 & & 341 & $\begin{array}{l}323 ; 260 ; 199 ; \\
168\end{array}$ & {$[81,92]$} \\
\hline
\end{tabular}


Table A1. Cont.

\begin{tabular}{|c|c|c|c|c|c|c|c|}
\hline \multirow{2}{*}{ ID } & \multirow{2}{*}{ Identified Compound } & \multirow{2}{*}{$\begin{array}{c}\text { Molecular } \\
\text { Formula }\end{array}$} & \multirow{2}{*}{$\begin{array}{l}\text { Calculated } \\
\text { Mass }\end{array}$} & \multicolumn{2}{|c|}{ Observed Mass } & \multirow{2}{*}{$\begin{array}{c}\text { Fragment Ions, } \\
m / z\end{array}$} & \multirow[b]{2}{*}{ References } \\
\hline & & & & {$[\mathbf{M}-\mathbf{H}]^{-}$} & {$[\mathbf{M}+\mathbf{H}]^{+}$} & & \\
\hline \multicolumn{8}{|c|}{ Lignan } \\
\hline 74 & $\begin{array}{c}\text { Dimethyl- } \\
\text { secoisolariciresinol }\end{array}$ & $\mathrm{C}_{22} \mathrm{H}_{30} \mathrm{O}_{6}$ & 390.4700 & & 391 & $\begin{array}{l}355 ; 336 ; 308 \\
218 ; 149\end{array}$ & [93] \\
\hline 75 & Hinokinin & $\mathrm{C}_{20} \mathrm{H}_{18} \mathrm{O}_{6}$ & 354.3533 & & 355 & $\begin{array}{l}336 ; 318 ; 300 \\
207 ; 181 ; 177\end{array}$ & {$[28,30,54]$} \\
\hline 76 & Pinoresinol & $\mathrm{C}_{20} \mathrm{H}_{22} \mathrm{O}_{6}$ & 358.3851 & 357 & & $\begin{array}{c}339 ; 311 ; 267 ; \\
213 ; 197 ; 171 ; \\
155 ; 139\end{array}$ & {$[28,30,34]$} \\
\hline 77 & $\begin{array}{c}\text { Podophyllotoxin } \\
\text { [Podofilox; Condylox; } \\
\text { Condyline; Podophyllinic } \\
\text { acid lactone] }\end{array}$ & $\mathrm{C}_{22} \mathrm{H}_{22} \mathrm{O}_{8}$ & 414.4053 & & 415 & $\begin{array}{l}397 ; 379 ; 310 ; \\
275 ; 250 ; 182\end{array}$ & [93] \\
\hline 78 & Syringaresinol & $\mathrm{C}_{22} \mathrm{H}_{26} \mathrm{O}_{8}$ & 418.4436 & & 419 & $\begin{array}{l}357 ; 327 ; 275 \\
\quad 185 ; 158\end{array}$ & [54] \\
\hline \multicolumn{8}{|c|}{ Phenolic Acid } \\
\hline 79 & $\begin{array}{l}\text { 1-O-caffeoyl-5-O- } \\
\text { feruloylquinic } \\
\text { acid }\end{array}$ & $\mathrm{C}_{26} \mathrm{H}_{26} \mathrm{O}_{12}$ & 530.4774 & & 531 & $\begin{array}{l}513 ; 415 ; 337 ; \\
195 ; 176 ; 115\end{array}$ & [52] \\
\hline 80 & $\begin{array}{c}\text { 4-O-Caffeoyl-5-O- } p \text { - } \\
\text { coumaroylquinic } \\
\text { acid }\end{array}$ & $\mathrm{C}_{25} \mathrm{H}_{24} \mathrm{O}_{11}$ & 500.4515 & & 501 & $\begin{array}{c}339 ; 244 ; 189 \\
140\end{array}$ & {$[55,84]$} \\
\hline 81 & Feruloyl sulfate & $\mathrm{C}_{10} \mathrm{H}_{10} \mathrm{O}_{7} \mathrm{~S}$ & 274.2472 & 273 & & $193 ; 192 ; 149$ & [94] \\
\hline 82 & Gallic acid hexoside & $\mathrm{C}_{13} \mathrm{H}_{16} \mathrm{O}_{10}$ & 332.2601 & & 333 & $\begin{array}{l}242 ; 212 ; 182 \\
159\end{array}$ & [95] \\
\hline \multicolumn{8}{|c|}{ Stilbene } \\
\hline 83 & $\begin{array}{c}\text { Pinosylvin } \\
\text { [3,5-Stilbenediol; Trans- } \\
\text { 3,5-Dihydroxystilbene] }\end{array}$ & $\mathrm{C}_{14} \mathrm{H}_{12} \mathrm{O}_{2}$ & 212.2439 & & 213 & $\begin{array}{c}197 ; 183 ; 166 ; \\
124\end{array}$ & [96] \\
\hline 84 & $\begin{array}{l}\text { Polydatin [Piceid; } \\
\text { trans-Piceid] }\end{array}$ & $\mathrm{C}_{20} \mathrm{H}_{22} \mathrm{O}_{8}$ & 390.3839 & & 391 & $\begin{array}{l}355 ; 333 ; 265 ; \\
227 ; 209 ; 145\end{array}$ & {$[73,77]$} \\
\hline 85 & $\begin{array}{c}\text { Resveratrol } \\
\text { [trans-Resveratrol; } \\
\text { 3,4',5-Trihydroxystilbene; } \\
\text { Stilbentriol] }\end{array}$ & $\mathrm{C}_{14} \mathrm{H}_{12} \mathrm{O}_{3}$ & 228.2433 & & 229 & $228 ; 142 ; 114$ & {$[37,73]$} \\
\hline \multicolumn{8}{|c|}{ Other Compounds } \\
\hline 86 & Undecanedioic acid & $\mathrm{C}_{11} \mathrm{H}_{20} \mathrm{O}_{4}$ & 216.2741 & & 217 & $\begin{array}{l}\text { 173; 157; 142; } \\
\text { 118; } 115\end{array}$ & [34] \\
\hline 87 & $\begin{array}{c}\text { Myristoleic acid } \\
\text { [Cis-9-Tetradecanoic acid] }\end{array}$ & $\mathrm{C}_{14} \mathrm{H}_{26} \mathrm{O}_{2}$ & 226.3550 & & 227 & $\begin{array}{l}\text { 209; } 138 ; 127 \\
110\end{array}$ & [34] \\
\hline 88 & $\begin{array}{l}\text { 11-Hydroperoxy- } \\
\text { octadecatrienoic } \\
\text { acid }\end{array}$ & $\mathrm{C}_{18} \mathrm{H}_{30} \mathrm{O}_{4}$ & 310.4284 & 309 & & $\begin{array}{l}291 ; 209 ; 207 ; \\
125\end{array}$ & [97] \\
\hline 89 & $\begin{array}{c}\text { 9,10-Dihydroxy-8- } \\
\text { oxooctadec-12-enoic acid } \\
\text { [oxo-DHODE; oxo- } \\
\text { Dihydroxy-octadecenoic } \\
\text { acid] }\end{array}$ & $\mathrm{C}_{18} \mathrm{H}_{32} \mathrm{O}_{5}$ & 328.4437 & 327 & & $\begin{array}{l}229 ; 211 ; 171 ; \\
\quad 135 ; 125\end{array}$ & {$[35,36]$} \\
\hline 90 & $\begin{array}{l}\text { Dihydroxy docosanoic } \\
\text { acid }\end{array}$ & $\mathrm{C}_{22} \mathrm{H}_{44} \mathrm{O}_{4}$ & 372.5824 & 371 & & $\begin{array}{l}327 ; 297 ; 282 ; \\
251 ; 187 ; 125\end{array}$ & [34] \\
\hline 91 & $\begin{array}{c}\text { Docosenoic acid } \\
\text { [2-Docosenoic acid]) }\end{array}$ & $\mathrm{C}_{22} \mathrm{H}_{42} \mathrm{O}_{2}$ & 338.5677 & & 339 & $\begin{array}{l}322 ; 295 ; 256 \\
215 ; 163\end{array}$ & [34] \\
\hline 92 & $\begin{array}{l}\text { Hydroxy methoxy } \\
\text { dimethylbenzoic acid }\end{array}$ & $\mathrm{C}_{10} \mathrm{H}_{12} \mathrm{O}_{4}$ & 196.1999 & 195 & & $177 ; 129$ & [34] \\
\hline
\end{tabular}


Table A1. Cont.

\begin{tabular}{|c|c|c|c|c|c|c|c|}
\hline \multirow{2}{*}{ ID } & \multirow{2}{*}{ Identified Compound } & \multirow{2}{*}{$\begin{array}{l}\text { Molecular } \\
\text { Formula }\end{array}$} & \multirow{2}{*}{$\begin{array}{l}\text { Calculated } \\
\text { Mass }\end{array}$} & \multicolumn{2}{|c|}{ Observed Mass } & \multirow{2}{*}{$\begin{array}{c}\text { Fragment Ions, } \\
\mathrm{m} / \mathrm{z}\end{array}$} & \multirow[b]{2}{*}{ References } \\
\hline & & & & {$[\mathbf{M}-\mathbf{H}]^{-}$} & {$[\mathbf{M}+\mathbf{H}]^{+}$} & & \\
\hline 93 & Pentacosenoic acid & $\mathrm{C}_{25} \mathrm{H}_{48} \mathrm{O}_{2}$ & 380.6474 & & 381 & $\begin{array}{c}363 ; 293 ; 173 ; \\
135\end{array}$ & [34] \\
\hline 94 & Salvianic acid $C$ & $\mathrm{C}_{18} \mathrm{H}_{18} \mathrm{O}_{9}$ & 378.3301 & & 379 & $\begin{array}{l}361 ; 343 ; 335 ; \\
326 ; 247 ; 237 ; \\
205 ; 151 ; 129\end{array}$ & [92] \\
\hline 95 & Vebonol & $\mathrm{C}_{30} \mathrm{H}_{44} \mathrm{O}_{3}$ & 452.6686 & & 453 & $435 ; 336 ; 209$ & [86] \\
\hline 96 & $\begin{array}{l}\text { Cyclopassifloic acid } \\
\text { glucoside }\end{array}$ & $\mathrm{C}_{37} \mathrm{H}_{62} \mathrm{O}_{12}$ & 698.8810 & & 699 & $\begin{array}{c}537 ; 421 ; 348 \\
203\end{array}$ & [31] \\
\hline 97 & $\begin{array}{c}\left(3 S, 3^{\prime} S, \text { all-E)-zeaxanthin }\right. \\
\text { [Zeaxanthin; } \\
\left(3 S, 3^{\prime} S\right) \text {-Zeaxanthin] }\end{array}$ & $\mathrm{C}_{40} \mathrm{H}_{56} \mathrm{O}_{2}$ & 568.8714 & & 569 & $\begin{array}{l}551 ; 375 ; 329 ; \\
279 ; 235 ; 210 ; \\
153\end{array}$ & [51] \\
\hline 98 & $\begin{array}{c}\text { Cryptoxanthin } \\
\text { [ } \beta \text {-cryptoxanthin] }\end{array}$ & $\mathrm{C}_{40} \mathrm{H}_{56} \mathrm{O}$ & 552.872 & & 553 & $461 ; 337 ; 199$ & [51] \\
\hline 99 & Isocryptotanshinone II & $\mathrm{C}_{19} \mathrm{H}_{20} \mathrm{O}_{3}$ & 296.3603 & & 297 & $279 ; 149 ; 146$ & [98] \\
\hline 100 & $\begin{array}{c}\text { Tanshinone IIB } \\
\text { [(S)-6-(Hydroxymethyl)- } \\
\text { 1,6-Dimethyl-6,7,8,9- } \\
\text { Tetrahydrophenanthro } \\
\text { [1,2-B]Furan-10,11- } \\
\text { Dione] }\end{array}$ & $\mathrm{C}_{19} \mathrm{H}_{18} \mathrm{O}_{4}$ & 310.3438 & 309 & & $\begin{array}{l}291 ; 273 ; 251 ; \\
235 ; 209 ; 207 ; \\
122\end{array}$ & [98] \\
\hline 101 & $\begin{array}{c}\beta \text {-Amyrin [ } \beta \text {-Amyrenol; } \\
\text { Amyrin; } \\
\text { Olean-12-en-3 } \beta \text {-ol] }\end{array}$ & $\mathrm{C}_{30} \mathrm{H}_{50} \mathrm{O}$ & 426.7174 & & 427 & $\begin{array}{l}409 ; 391 ; 373 ; \\
292 ; 269 ; 240 ; \\
190 ; 145 ; 137\end{array}$ & [34] \\
\hline 102 & Gibberellic acid & $\mathrm{C}_{19} \mathrm{H}_{22} \mathrm{O}_{6}$ & 346.3744 & & 347 & $\begin{array}{l}301 ; 282 ; 263 ; \\
242 ; 201 ; 185 ; \\
139\end{array}$ & [99] \\
\hline 103 & Betunolic acid & $\mathrm{C}_{30} \mathrm{H}_{46} \mathrm{O}_{3}$ & 454.3446 & & 455 & $\begin{array}{c}436 ; 355 ; 236 ; \\
226\end{array}$ & [86] \\
\hline 104 & Ursolic acid & $\mathrm{C}_{30} \mathrm{H}_{48} \mathrm{O}_{3}$ & 456.7003 & & 457 & $\begin{array}{c}439 ; 263 ; 177 ; \\
145\end{array}$ & {$[52,56,81,100]$} \\
\hline 105 & $\begin{array}{l}\text { Squalene (Trans-Squalene; } \\
\text { Spinacene; Supraene) }\end{array}$ & $\mathrm{C}_{30} \mathrm{H}_{50}$ & 410.718 & & 411 & $\begin{array}{c}235 ; 218 ; 177 ; \\
147\end{array}$ & {$[101,102]$} \\
\hline 106 & Uvaol & $\mathrm{C}_{30} \mathrm{H}_{50} \mathrm{O}_{2}$ & 442.7168 & & 443 & $\begin{array}{l}425 ; 407 ; 315 ; \\
304 ; 287 ; 230 ; \\
\quad 154 ; 137\end{array}$ & [34] \\
\hline 107 & L-Histidine & $\mathrm{C}_{6} \mathrm{H}_{9} \mathrm{~N}_{3} \mathrm{O}_{2}$ & 155.1546 & & 156 & $\ldots$ & [103] \\
\hline 108 & $\begin{array}{l}\text { L-Tryptophan } \\
\text { [Tryptophan; } \\
\text { (S)-Tryptophan] }\end{array}$ & $\mathrm{C}_{11} \mathrm{H}_{12} \mathrm{~N}_{2} \mathrm{O}_{2}$ & 204.2252 & & 205 & $188 ; 146 ; 118$ & {$[34,91,104]$} \\
\hline 109 & L-Valine & $\mathrm{C}_{5} \mathrm{H}_{11} \mathrm{NO}_{2}$ & 117.1463 & & 118 & $\ldots$ & [103] \\
\hline 110 & $\begin{array}{l}\text { Tyrosine [(2S)-2-Amino-3- } \\
\text { (4-Hydroxyphnyl) } \\
\text { Propanoic acid] }\end{array}$ & $\mathrm{C}_{9} \mathrm{H}_{11} \mathrm{NO}_{3}$ & 181.19 & & 182 & $155 ; 127 ; 116$ & [104] \\
\hline 111 & Sespendole & $\mathrm{C}_{33} \mathrm{H}_{45} \mathrm{NO}_{4}$ & 519.7147 & & 520 & $184 ; 125$ & [86] \\
\hline 112 & $\begin{array}{c}\text { Berberine [Berberin; } \\
\text { Umbelletine; Berbericine] }\end{array}$ & $\mathrm{C}_{20} \mathrm{H}_{18} \mathrm{NO}_{4}$ & 336.3612 & & 337 & $\begin{array}{l}320 ; 303 ; 207 \\
206 ; 115\end{array}$ & [105] \\
\hline 113 & GA8-hexose gibberellin & $\mathrm{C}_{25} \mathrm{H}_{34} \mathrm{O}_{12}$ & 526.5303 & & 527 & $\begin{array}{l}365 ; 305 ; 275 ; \\
245 ; 203 ; 143\end{array}$ & [91] \\
\hline 114 & $\begin{array}{c}\text { Abscisic acid [Dormin; } \\
\text { Abscisin II; } \\
\text { (S)-(+)-Abscisic acid] }\end{array}$ & $\mathrm{C}_{15} \mathrm{H}_{20} \mathrm{O}_{4}$ & 264.3169 & & 265 & $247 ; 122$ & [99] \\
\hline 115 & $\begin{array}{l}\text { Ketoprofen [Orudis; } \\
\text { 2-(3-Benzoylphenyl) } \\
\text { Propionic acid; Profenid] }\end{array}$ & $\mathrm{C}_{16} \mathrm{H}_{14} \mathrm{O}_{3}$ & 254.2806 & 253 & & $\begin{array}{l}209 ; 191 ; 165 ; \\
121\end{array}$ & [106] \\
\hline
\end{tabular}


Table A1. Cont.

\begin{tabular}{|c|c|c|c|c|c|c|c|}
\hline \multirow{2}{*}{ ID } & \multirow{2}{*}{ Identified Compound } & \multirow{2}{*}{$\begin{array}{l}\text { Molecular } \\
\text { Formula }\end{array}$} & \multirow{2}{*}{$\begin{array}{l}\text { Calculated } \\
\text { Mass }\end{array}$} & \multicolumn{2}{|c|}{ Observed Mass } & \multirow{2}{*}{$\begin{array}{l}\text { Fragment Ions, } \\
\mathrm{m} / \mathrm{z}\end{array}$} & \multirow[b]{2}{*}{ References } \\
\hline & & & & {$[\mathbf{M}-\mathbf{H}]^{-}$} & {$[\mathrm{M}+\mathrm{H}]^{+}$} & & \\
\hline 116 & Adenosine & $\mathrm{C}_{10} \mathrm{H}_{13} \mathrm{~N}_{5} \mathrm{O}_{4}$ & 267.2413 & & 268 & 136 & [103] \\
\hline 117 & $\begin{array}{l}\text { Ergosterol [Provitamin } \\
\text { D2; Ergosterin] }\end{array}$ & $\mathrm{C}_{28} \mathrm{H}_{44} \mathrm{O}$ & 396.6484 & & 397 & $\begin{array}{c}379 ; 361 ; 309 ; \\
282 ; 239 ; 189 ; \\
125\end{array}$ & [34] \\
\hline 118 & $\begin{array}{c}\text { Avenasterol } \\
\text { [Delta7-Avenasterol; } \\
\text { 7-Dehydroavenasterol] }\end{array}$ & $\mathrm{C}_{29} \mathrm{H}_{48} \mathrm{O}$ & 412.6908 & & 413 & $\begin{array}{l}395 ; 376 ; 358 ; \\
336 ; 325 ; 271 ; \\
269 ; 251 ; 225 ; \\
224 ; 201 ; 165 ; \\
159 ; 124\end{array}$ & [34] \\
\hline 119 & $\begin{array}{c}\beta \text {-Sitostenone } \\
\text { [Stigmast-4-En-3-One; } \\
\text { Sitostenone] }\end{array}$ & $\mathrm{C}_{29} \mathrm{H}_{48} \mathrm{O}$ & 412.6908 & & 413 & $\begin{array}{l}493 ; 375 ; 358 ; \\
269 ; 261 ; 235 ; \\
152 ; 147\end{array}$ & [34] \\
\hline 120 & $\beta$-Sitosterin $[\beta$-Sitosterol] & $\mathrm{C}_{29} \mathrm{H}_{50} \mathrm{O}$ & 414.7067 & & 415 & $\begin{array}{c}395 ; 377 ; 297 \\
268 ; 213 ; 163 \\
133 ;\end{array}$ & {$[37,100]$} \\
\hline 121 & Campestenone & $\mathrm{C}_{28} \mathrm{H}_{46} \mathrm{O}$ & 398.6642 & & 399 & $\begin{array}{l}337 ; 319 ; 311 ; \\
266 ; 239 ; 189 ; \\
182 ; 127\end{array}$ & [34] \\
\hline 122 & $\begin{array}{c}\text { Fucosterol [Fucostein; } \\
\text { Trans-24- } \\
\text { Ethylidenecholesterol] }\end{array}$ & $\mathrm{C}_{29} \mathrm{H}_{48} \mathrm{O}$ & 412.6908 & & 413 & $\begin{array}{l}395 ; 375 ; 355 ; \\
340 ; 303 ; 267 ; \\
201 ; 195 ; 167 ; \\
\quad 121\end{array}$ & [34] \\
\hline 123 & Oxo-hydroxy sitosterol & $\mathrm{C}_{29} \mathrm{H}_{48} \mathrm{O}_{3}$ & 444.6896 & & 445 & $\begin{array}{l}427 ; 385 ; 319 ; \\
205 ; 165 ; 164 ; \\
137\end{array}$ & [34] \\
\hline 124 & Vapiprost & $\mathrm{C}_{30} \mathrm{H}_{39} \mathrm{NO}_{4}$ & 477.6350 & & 478 & $337 ; 121 ; 263$ & [86] \\
\hline 125 & $\begin{array}{l}\text { Hexadecatrienoic acid } \\
\text { [Hexadeca-2,4,6-trienoic } \\
\text { acid] }\end{array}$ & $\mathrm{C}_{16} \mathrm{H}_{26} \mathrm{O}_{2}$ & 250.3764 & & 251 & $233 ; 204 ; 147$ & [34] \\
\hline
\end{tabular}

\section{References}

1. Loskutov, I.G.; Khlestkina, E.K. Wheat, Barley, and Oat Breeding for Health Benefit Components in Grain. Plants 2021, 10, 86. [CrossRef] [PubMed]

2. Abdel-Aal, E.-S.M.; Young, J.C.; Rabalski, I. Anthocyanin composition in black, blue, pink, purple, and red cereal grains. J. Agr. Food Chem. 2006, 54, 4696-4704. [CrossRef] [PubMed]

3. Chalker-Scott, L. Environmental significance of anthocyanins in plant stress responses. Photochem. Photobiol. 1999, 70, 1-9. [CrossRef]

4. Tikhonova, M.A.; Shoeva, O.Y.; Tenditnik, M.V.; Ovsyukova, M.V.; Akopyan, A.A.; Dubrovina, N.I.; Amstislavskaya, T.G.; Khlestkina, E.K. Evaluating the Effects of Grain of Isogenic Wheat Lines Differing in the Content of Anthocyanins in Mouse Models of Neurodegenerative Disorders. Nutrients 2020, 12, 3877. [CrossRef]

5. Cavalcanti, R.N.; Santos, D.T.; Meireles, M.A.A. Non-thermal stabilization mechanisms of anthocyanins in model and food systems-An overview. Food Res. Int. 2011, 44, 499-509. [CrossRef]

6. Žilić, S.; Serpen, A.; Akıllığlu, G.; Gökmen, V.; Vančetović, J. Phenolic compounds, carotenoids, anthocyanins, and antioxidant capacity of colored maize (Zea mays L.) kernels. J. Agric. Food Chem. 2012, 60, 1224-1231. [CrossRef]

7. Zeven, A. Wheats with purple and blue grains: A review. Euphytica 1991, 56, 243-258. [CrossRef]

8. Khlestkina, E. Genes determining the coloration of different organs in wheat. Russ. J. Genet. Appl. Res. 2013, 3, 54-65. [CrossRef]

9. Khlestkina, E.; Shoeva, O.Y.; Gordeeva, E. Flavonoid biosynthesis genes in wheat. Russ. J. Genet. Appl. Res. 2015, 5, 268-278. [CrossRef]

10. Himi, E.; Maekawa, M.; Miura, H.; Noda, K. Development of PCR markers for Tamyb10 related to R-1, red grain color gene in wheat. Theoret. Appl. Genet. 2011, 122, 1561-1576. [CrossRef]

11. Shen, Y.; Shen, J.; Zhuang, L.; Wang, Y.; Pu, J.; Feng, Y.; Chu, C.; Wang, X.; Qi, Z. Physical localization of a novel blue-grained gene derived from Thinopyrum bessarabicum. Mol. Breed. 2013, 31, 195-204. [CrossRef]

12. Dubcovsky, J.; Luo, M.-C.; Zhong, G.-Y.; Bransteitter, R.; Desai, A.; Kilian, A.; Kleinhofs, A.; Dvořák, J. Genetic map of diploid wheat, Triticum monococcum L. and its comparison with maps of Hordeum vulgare L. Genetics 1996, 143, 983-999. [CrossRef]

13. Zheng, Q.; Li, B.; Mu, S.; Zhou, H.; Li, Z. Physical mapping of the blue-grained gene(s) from Thinopyrum ponticum by GISH and FISH in a set of translocation lines with different seed colors in wheat. Genome 2006, 49, 1109-1114. [CrossRef] 
14. McIntosh, R.A.; Hart, G.E.; Devos, K.M.; Gale, M.D.; Rogers, W.J. Catalogue of gene symbols for wheat. In Proceedings of the 9th International Wheat Genetics Symposium; Slinkard, A.E., Ed.; University Extension Press, University of Saskatchewan: Saskatoon, SK, Canada, 1998; pp. 1-235.

15. Dobrovolskaya, O.; Arbuzova, V.; Lohwasser, U.; Röder, M.; Börner, A. Microsatellite mapping of complementary genes for purple grain colour in bread wheat (Triticum aestivum) L. Euphytica 2006, 150, 355-364. [CrossRef]

16. Usenko, N.I.; Khlestkina, E.K.; Asavasanti, S.; Gordeeva, E.I.; Yudina, R.S.; Otmakhova, Y.S. Possibilities of enriching food products with anthocyanins by using new forms of cereals. Foods Raw Mater. 2018, 6, 128-135. [CrossRef]

17. Khlestkina, E.K.; Usenko, N.I.; Gordeeva, E.I.; Stabrovskaya, O.I.; Sharfunova, I.B.; Otmakhova, Y.S. Evaluation of wheat products with high flavonoid content: Justification of importance of marker-assisted development and production of flavonoid-rich wheat cultivars. Vavilov J. Genet. Breed. 2017, 21, 545-553. [CrossRef]

18. Bartl, P.; Albreht, A.; Skrt, M.; Tremlová, B.; Ošt'ádalová, M.; Šmejkal, K.; Vovk, I.; Ulrih, N.P. Anthocyanins in purple and blue wheat grains and in resulting bread: Quantity, composition, and thermal stability. Int. J. Food Sci. Nutr. 2015, 66, 514-519. [CrossRef]

19. Pasqualone, A.; Bianco, A.M.; Paradiso, V.M.; Summo, C.; Gambacorta, G.; Caponio, F.; Blanco, A. Production and characterization of functional biscuits obtained from purple wheat. Food Chem. 2015, 180, 64-70. [CrossRef]

20. Ficco, D.B.M.; De Simone, V.; De Leonardis, A.M.; Giovanniello, V.; Del Nobile, M.A.; Padalino, L.; Lecce, L.; Borrelli, G.M.; De Vita, P. Use of purple durum wheat to produce naturally functional fresh and dry pasta. Food Chem. 2016, 205, 187-195. [CrossRef] [PubMed]

21. Gamel, T.H.; Wright, A.J.; Pickard, M.; Abdel-Aal, E.S.M. Characterization of anthocyanin-containing purple wheat prototype products as functional foods with potential health benefits. Cereal Chem. 2020, 97, 34-38. [CrossRef]

22. Abdel-Aal, E.-S.M.; Hucl, P. Composition and stability of anthocyanins in blue-grained wheat. J. Agric. Food Chem. 2003, 51, 2174-2180. [CrossRef]

23. Hosseinian, F.S.; Li, W.; Beta, T. Measurement of anthocyanins and other phytochemicals in purple wheat. Food Chem. 2008, 109, 916-924. [CrossRef] [PubMed]

24. Devanand, L.L.; Lu, Y.; John, K.M.M. Bioactive phytochemicals in wheat: Extraction, analysis, processing, and functional properties. J. Funct. Foods 2015, 18, 910-925.

25. Gordeeva, E.; Badaeva, E.; Yudina, R.; Shchukina, L.; Shoeva, O.; Khlestkina, E. Marker-assisted development of a blue-grained substitution line carrying the Thinopyrum ponticum chromosome 4Th(4D) in the spring bread wheat Saratovskaya 29 background. Agronomy 2019, 9, 723. [CrossRef]

26. Gordeeva, E.; Badaeva, E.; Adonina, I.; Khlestkina, E.; Shoeva, O.Y. Marker-based development of wheat near-isogenic and substitution lines with high anthocyanin content in grains. In Current Challenges in Plant Genetics, Genomics, Bioinformatics, and Biotechnology: Proceedings of the Fifth International Scientific Conference PlantGen2019; Kochetov, A., Salina, E., Eds.; Institute of Cytology and Genetics, Siberian Branch of the Russian Academy of Sciences: Novosibirsk, Russia, 2019; p. 82.

27. Cavaliere, C.; Foglia, P.; Pastorini, E.; Samperi, R.; Laganà, A. Identification and mass spectrometric characterization of glycosylated flavonoids in Triticum durum plants by high-performance liquid chromatography with tandem mass spectrometry. Rapid Commun. Mass Spectrom. 2005, 19, 3143-3158. [CrossRef]

28. Dinelli, G.; Segura-Carretero, A.; Di Silvestro, R.; Marotti, I.; Arráez-Román, D.; Benedettelli, S.; Ghiselli, L.; Fernadez-Gutierrez, A. Profiles of phenolic compounds in modern and old common wheat varieties determined by liquid chromatography coupled with time-of-flight mass spectrometry. J. Chromatogr. A 2011, 1218, 7670-7681. [CrossRef] [PubMed]

29. Geng, P.; Sun, J.; Zhang, M.; Li, X.; Harnly, J.M.; Chen, P. Comprehensive characterization of C-glycosyl flavones in wheat (Triticum aestivum L.) germ using UPLC-PDA-ESI/HRMSn and mass defect filtering. J. Mass Spectrom. 2016, 51, 914-930. [CrossRef]

30. Leoncini, E.; Prata, C.; Malaguti, M.; Marotti, I.; Segura-Carretero, A.; Catizone, P.; Dinelli, G.; Hrelia, S. Phytochemical profile and nutraceutical value of old and modern common wheat cultivars. PLoS ONE 2012, 7, e45997. [CrossRef]

31. Garg, M.; Chawla, M.; Chunduri, V.; Kumar, R.; Sharma, S.; Sharma, N.K.; Kaur, N.; Kumar, A.; Mundey, J.K.; Saini, M.K. Transfer of grain colors to elite wheat cultivars and their characterization. J. Cereal Sci. 2016, 71, 138-144. [CrossRef]

32. Stallmann, J.; Schweiger, R.; Pons, C.A.; Müller, C. Wheat growth, applied water use efficiency and flag leaf metabolome under continuous and pulsed deficit irrigation. Sci. Rep. 2020, 10, 1-13.

33. Wojakowska, A.; Perkowski, J.; Góral, T.; Stobiecki, M. Structural characterization of flavonoid glycosides from leaves of wheat (Triticum aestivum L.) using LC/MS/MS profiling of the target compounds. J. Mass Spectrom. 2013, 48, 329-339. [CrossRef]

34. Ozarowski, M.; Piasecka, A.; Paszel-Jaworska, A.; de Chaves, D.S.A.; Romaniuk, A.; Rybczynska, M.; Gryszczynska, A.; Sawikowska, A.; Kachlicki, P.; Mikolajczak, P.L. Comparison of bioactive compounds content in leaf extracts of Passiflora incarnata, P. caerulea and P. alata and in vitro cytotoxic potential on leukemia cell lines. Rev. Bras. Farmacogn. 2018, 28, 179-191. [CrossRef]

35. Llorent-Martínez, E.J.; Spínola, V.; Gouveia, S.; Castilho, P.C. HPLC-ESI-MSn characterization of phenolic compounds, terpenoid saponins, and other minor compounds in Bituminaria bituminosa. Ind. Crop. Prod. 2015, 69, 80-90. [CrossRef]

36. Van Hoyweghen, L.; De Bosscher, K.; Haegeman, G.; Deforce, D.; Heyerick, A. In vitro inhibition of the transcription factor NF- $k B$ and cyclooxygenase by Bamboo extracts. Phytother. Res. 2014, 28, 224-230. [CrossRef] 
37. Hamed, A.R.; El-Hawary, S.S.; Ibrahim, R.M.; Abdelmohsen, U.R.; El-Halawany, A.M. Identification of chemopreventive components from halophytes belonging to Aizoaceae and Cactaceae through LC/MS-Bioassay guided approach. J. Chromatogr. Sci. 2020, 59, 618-626. [CrossRef] [PubMed]

38. Rafsanjany, N.; Senker, J.; Brandt, S.; Dobrindt, U.; Hensel, A. In vivo consumption of cranberry exerts ex vivo antiadhesive activity against FimH-dominated uropathogenic Escherichia coli: A combined in vivo, ex vivo, and in vitro study of an extract from Vaccinium macrocarpon. J. Agric. Food Chem. 2015, 63, 8804-8818. [CrossRef] [PubMed]

39. Andersen, O.M.; Markham, K.R. Flavonoids: Chemistry, Biochemistry and Applications; CRC Press: Boca Raton, FL, USA, 2005.

40. Yang, M.; I Koo, S.; O Song, W.; K Chun, O. Food matrix affecting anthocyanin bioavailability. Curr. Med. Chem. 2011, 18, 291-300. [CrossRef] [PubMed]

41. Lucioli, S. Chapter 3: Anthocyanins: Mechanism of action and therapeutic efficacy. In Medicinal Plants as Antioxidant Agents: Understanding Their Mechanism of Action and Therapeutic Efficacy; Capasso, A., Ed.; Research Signpost: Kerala, India, 2012; pp. 27-57, ISBN 97881-308-0509-2.

42. Matsumoto, H.; Nakamura, Y.; Tachibanaki, S.; Kawamura, S.; Hirayama, M. Stimulatory effect of cyanidin 3-glycosides on the regeneration of rhodopsin. J. Agric. Food Chem. 2003, 51, 3560-3563. [CrossRef] [PubMed]

43. Zhang, Y.; Seeram, N.P.; Lee, R.; Feng, L.; Heber, D. Isolation and identification of strawberry phenolics with antioxidant and human cancer cell antiproliferative properties. J. Agric. Food Chem. 2008, 56, 670-675. [CrossRef]

44. Cvorovic, J.; Tramer, F.; Granzotto, M.; Candussio, L.; Decorti, G.; Passamonti, S. Oxidative stress-based cytotoxicity of delphinidin and cyanidin in colon cancer cells. Arch. Biochem. Biophys. 2010, 501, 151-157. [CrossRef]

45. Hou, D.-X. Potential mechanisms of cancer chemoprevention by anthocyanins. Curr. Mol. Med. 2003, 3, 149-159. [CrossRef]

46. Gordeeva, E.; Shamanin, V.; Shoeva, O.; Kukoeva, T.; Morgounov, A.; Khlestkina, E. The strategy for marker-assisted breeding of anthocyanin-rich spring bread wheat (Triticum aestivum L.) cultivars in Western Siberia. Agronomy 2020, 10, 1603. [CrossRef]

47. Arbuzova, V.; Maystrenko, O.; Popova, O. Development of near-isogenic lines of the common wheat cultivar 'Saratovskaya 29'. Cereal Res. Commun. 1998, 26, 39-46. [CrossRef]

48. Tereshchenko, O.Y.; Gordeeva, E.I.; Arbuzova, V.S.; Börner, A.; Khlestkina, E.K. The D Genome Carries a Gene Determining Purple Grain Colour in Wheat. Cereal Res. Commun. 2012, 40, 334-341. [CrossRef]

49. Cirlini, M.; Mena, P.; Tassotti, M.; Herrlinger, K.A.; Nieman, K.M.; Dall'Asta, C.; Del Rio, D. Phenolic and volatile composition of a dry spearmint (Mentha spicata L.) extract. Molecules 2016, 21, 1007. [CrossRef]

50. Marzouk, M.M.; Hussein, S.R.; Elkhateeb, A.; El-shabrawy, M.; Abdel-Hameed, E.-S.S.; Kawashty, S.A. Comparative study of Mentha species growing wild in Egypt: LC-ESI-MS analysis and chemosystematic significance. J. Appl. Pharm. Sci. 2018, 8 , 116-122.

51. Mercadante, A.Z.; Rodrigues, D.B.; Petry, F.C.; Mariutti, L.R.B. Carotenoid esters in foods-A review and practical directions on analysis and occurrence. Food Res. Int. 2017, 99, 830-850. [CrossRef] [PubMed]

52. Pandey, R.; Kumar, B. HPLC-QTOF-MS/MS-based rapid screening of phenolics and triterpenic acids in leaf extracts of Ocimum species and their interspecies variation. J. Liq. Chromatogr. Relat. Technol. 2016, 39, 225-238. [CrossRef]

53. Santos, S.A.; Vilela, C.; Freire, C.S.; Neto, C.P.; Silvestre, A.J. Ultra-high performance liquid chromatography coupled to mass spectrometry applied to the identification of valuable phenolic compounds from Eucalyptus wood. J. Chromatogr. B 2013, 938, 65-74. [CrossRef] [PubMed]

54. Sharma, M.; Sandhir, R.; Singh, A.; Kumar, P.; Mishra, A.; Jachak, S.; Singh, S.P.; Singh, J.; Roy, J. Comparative analysis of phenolic compound characterization and their biosynthesis genes between two diverse bread wheat (Triticum aestivum) varieties differing for chapatti (unleavened flat bread) quality. Front. Plant Sci. 2016, 7, 1870. [CrossRef]

55. Spínola, V.; Pinto, J.; Castilho, P.C. Identification and quantification of phenolic compounds of selected fruits from Madeira Island by HPLC-DAD-ESI-MSn and screening for their antioxidant activity. Food Chem. 2015, 173, 14-30. [CrossRef] [PubMed]

56. Sun, L.; Tao, S.; Zhang, S. Characterization and quantification of polyphenols and triterpenoids in thinned young fruits of ten pear varieties by UPLC-Q TRAP-MS/MS. Molecules 2019, 24, 159. [CrossRef]

57. Vallverdú-Queralt, A.; Jáuregui, O.; Medina-Remon, A.; Lamuela-Raventós, R.M. Evaluation of a method to characterize the phenolic profile of organic and conventional tomatoes. J. Agric. Food Chem. 2012, 60, 3373-3380. [CrossRef] [PubMed]

58. StatSoft, Inc. STATISTICA (Data Analysis Software System), Version 10: New Features and Enhancements; StatSoft: Tulsa, OK, USA, 2011.

59. Ruiz, A.; Hermosín-Gutiérrez, I.; Vergara, C.; von Baer, D.; Zapata, M.; Hitschfeld, A.; Obando, L.; Mardones, C. Anthocyanin profiles in south Patagonian wild berries by HPLC-DAD-ESI-MS/MS. Food Res. Int. 2013, 51, 706-713. [CrossRef]

60. Chen, W.; Gong, L.; Guo, Z.; Wang, W.; Zhang, H.; Liu, X.; Yu, S.; Xiong, L.; Luo, J. A novel integrated method for large-scale detection, identification, and quantification of widely targeted metabolites: Application in the study of rice metabolomics. Mol. Plant 2013, 6, 1769-1780. [CrossRef] [PubMed]

61. Ruiz, A.; Hermosin-Gutierrez, I.; Mardones, C.; Vergara, C.; Herlitz, E.; Vega, M.; Dorau, C.; Winterhalter, P.; von Baer, D. Polyphenols and antioxidant activity of calafate (Berberis microphylla) fruits and other native berries from Southern Chile. J. Agric. Food Chem. 2010, 58, 6081-6089. [CrossRef] [PubMed]

62. Pradhan, P.C.; Saha, S. Anthocyanin profiling of Berberis lycium Royle berry and its bioactivity evaluation for its nutraceutical potential. J. Food Sci. Technol. 2016, 53, 1205-1213. [CrossRef] 
63. Goufo, P.; Singh, R.K.; Cortez, I. A Reference list of phenolic compounds (including stilbenes) in grapevine (Vitis vinifera L.) roots, woods, canes, stems, and leaves. Antioxidants 2020, 9, 398. [CrossRef]

64. Thomford, N.E.; Dzobo, K.; Chopera, D.; Wonkam, A.; Maroyi, A.; Blackhurst, D.; Dandara, C. In vitro reversible and timedependent CYP450 inhibition profiles of medicinal herbal plant extracts Newbouldia laevis and Cassia abbreviata: Implications for herb-drug interactions. Molecules 2016, 21, 891. [CrossRef]

65. El-sayed, M.; Abbas, F.A.; Refaat, S.; El-Shafae, A.M.; Fikry, E. UPLC-ESI-MS/MS Profile of The Ethyl Acetate Fraction of Aerial Parts of Bougainvillea'Scarlett O'Hara'Cultivated in Egypt. Egypt. J. Chem. 2021, 64, 6-7.

66. Yasir, M.; Sultana, B.; Anwar, F. LC-ESI-MS/MS based characterization of phenolic components in fruits of two species of Solanaceae. J. Food Sci. Technol. 2018, 55, 2370-2376. [CrossRef]

67. Santos, S.A.O.; Freire, C.S.; Domingues, M.R.M.; Silvestre, A.J.; Neto, C.P. Characterization of phenolic components in polar extracts of Eucalyptus globulus Labill. bark by high-performance liquid chromatography-mass spectrometry. J. Agric. Food Chem. 2011, 59, 9386-9393. [CrossRef]

68. Abeywickrama, G.; Debnath, S.C.; Ambigaipalan, P.; Shahidi, F. Phenolics of selected cranberry genotypes (Vaccinium macrocarpon Ait.) and their antioxidant efficacy. J. Agric. Food Chem. 2016, 64, 9342-9351. [CrossRef]

69. Yasuda, T.; Fukui, M.; Nakazawa, T.; Hoshikawa, A.; Ohsawa, K. Metabolic Fate of Fraxin Administered Orally to Rats. J. Nat. Prod. 2006, 69, 755-757. [CrossRef] [PubMed]

70. Wang, H.; Xiao, B.; Hao, Z.; Sun, Z. Simultaneous determination of fraxin and its metabolite, fraxetin, in rat plasma by liquid chromatography-tandem mass spectrometry and its application in a pharmacokinetic study. J. Chromatogr. B 2016, 1017, 70-74. [CrossRef] [PubMed]

71. Wang, Z.; Zhu, W.; Liu, H.; Wu, G.; Song, M.; Yang, B.; Yang, D.; Wang, Q.; Kuang, H. Simultaneous Determination of Aesculin, Aesculetin, Fraxetin, Fraxin and Polydatin in Beagle Dog Plasma by UPLC-ESI-MS/MS and Its Application in a Pharmacokinetic Study after Oral Administration Extracts of Ledum palustre L. Molecules 2018, 23, 2285. [CrossRef] [PubMed]

72. Fan, Z.; Wang, Y.; Yang, M.; Cao, J.; Khan, A.; Cheng, G. UHPLC-ESI-HRMS/MS analysis on phenolic compositions of different E Se tea extracts and their antioxidant and cytoprotective activities. Food Chem. 2020, 318, 126512. [CrossRef]

73. Sun, J.; Liang, F.; Bin, Y.; Li, P.; Duan, C. Screening non-colored phenolics in red wines using liquid chromatography/ultraviolet and mass spectrometry/mass spectrometry libraries. Molecules 2007, 12, 679-693. [CrossRef]

74. Sharma, S.; Pandey, A.K.; Singh, K.; Upadhyay, S.K. Molecular characterization and global expression analysis of lectin receptor kinases in bread wheat (Triticum aestivum). PLoS ONE 2016, 11, e0153925.

75. Schoedl, K.; Forneck, A.; Sulyok, M.; Schuhmacher, R. Optimization, in-house validation, and application of a liquid chromatography-tandem mass spectrometry (LC-MS/MS)-based method for the quantification of selected polyphenolic compounds in leaves of grapevine (Vitis vinifera L.). J. Agric. Food Chem. 2011, 59, 10787-10794. [CrossRef]

76. De Rosso, M.; Panighel, A.; Vedova, A.D.; Gardiman, M.; Flamini, R. Characterization of Non-Anthocyanic Flavonoids in Some Hybrid Red Grape Extracts Potentially Interesting for Industrial Uses. Molecules 2015, 20, 18095-18106. [CrossRef] [PubMed]

77. Paudel, L.; Wyzgoski, F.J.; Scheerens, J.C.; Chanon, A.M.; Reese, R.N.; Smiljanic, D.; Wesdemiotis, C.; Blakeslee, J.J.; Riedl, K.M.; Rinaldi, P.L. Nonanthocyanin secondary metabolites of black raspberry (Rubus occidentalis L.) fruits: Identification by HPLC-DAD, NMR, HPLC-ESI-MS, and ESI-MS/MS analyses. J. Agric. Food Chem. 2013, 61, 12032-12043. [CrossRef] [PubMed]

78. Bodalska, A.; Kowalczyk, A.; Włodarczyk, M.; Fecka, I. Analysis of Polyphenolic Composition of a Herbal Medicinal ProductPeppermint Tincture. Molecules 2020, 25, 69. [CrossRef] [PubMed]

79. Wojakowska, A.; Piasecka, A.; García-López, P.M.; Zamora-Natera, F.; Krajewski, P.; Marczak, Ł.; Kachlicki, P.; Stobiecki, M. Structural analysis and profiling of phenolic secondary metabolites of Mexican lupine species using LC-MS techniques. Phytochemistry 2013, 92, 71-86. [CrossRef] [PubMed]

80. Fischer, U.A.; Carle, R.; Kammerer, D.R. Identification and quantification of phenolic compounds from pomegranate (Punica granatum L.) peel, mesocarp, aril and differently produced juices by HPLC-DAD-ESI/MSn. Food Chem. 2011, 127, 807-821. [CrossRef]

81. Xu, L.-L.; Xu, J.-J.; Zhong, K.-R.; Shang, Z.-P.; Wang, F.; Wang, R.-F.; Zhang, L.; Zhang, J.-Y.; Liu, B. Analysis of non-volatile chemical constituents of Menthae Haplocalycis herba by ultra-high performance liquid chromatography-high resolution mass spectrometry. Molecules 2017, 22, 1756. [CrossRef]

82. Di Loreto, A.; Bosi, S.; Montero, L.; Bregola, V.; Marotti, I.; Sferrazza, R.E.; Dinelli, G.; Herrero, M.; Cifuentes, A. Determination of phenolic compounds in ancient and modern durum wheat genotypes. Electrophoresis 2018, 39, 2001-2010. [CrossRef]

83. Zhang, Z.; Jia, P.; Zhang, X.; Zhang, Q.; Yang, H.; Shi, H.; Zhang, L. LC-MS/MS determination and pharmacokinetic study of seven flavonoids in rat plasma after oral administration of Cirsium japonicum DC. extract. J. Ethnopharmacol. 2014, 158, 66-75. [CrossRef]

84. Jaiswal, R.; Müller, H.; Müller, A.; Karar, M.G.E.; Kuhnert, N. Identification and characterization of chlorogenic acids, chlorogenic acid glycosides and flavonoids from Lonicera henryi L. (Caprifoliaceae) leaves by LC-MSn. Phytochemistry 2014, 108, $252-263$. [CrossRef]

85. Gordon, A.; Schadow, B.; Quijano, C.E.; Marx, F. Chemical characterization and antioxidant capacity of berries from Clidemia rubra (Aubl.) Mart. (Melastomataceae). Food Res. Int. 2011, 44, 2120-2127. [CrossRef]

86. Abu-Reidah, I.M.; Ali-Shtayeh, M.S.; Jamous, R.M.; Arráez-Román, D.; Segura-Carretero, A. HPLC-DAD-ESI-MS/MS screening of bioactive components from Rhus coriaria L. (Sumac) fruits. Food Chem. 2015, 166, 179-191. [CrossRef] 
87. Vieira, M.N.; Winterhalter, P.; Jerz, G. Flavonoids from the flowers of Impatiens glandulifera Royle isolated by high performance countercurrent chromatography. Phytochem. Anal. 2016, 27, 116-125. [CrossRef]

88. Xu, X.; Yang, B.; Wang, D.; Zhu, Y.; Miao, X.; Yang, W. The Chemical Composition of Brazilian Green Propolis and Its Protective Effects on Mouse Aortic Endothelial Cells against Inflammatory Injury. Molecules 2020, 25, 4612. [CrossRef]

89. Xiao, J.; Wang, T.; Li, P.; Liu, R.; Li, Q.; Bi, K. Development of two step liquid-liquid extraction tandem UHPLC-MS/MS method for the simultaneous determination of Ginkgo flavonoids, terpene lactones and nimodipine in rat plasma: Application to the pharmacokinetic study of the combination of Ginkgo biloba dispersible tablets and Nimodipine tablets. J. Chromatogr. B 2016, 1028, 33-41.

90. Zhou, J.-M.; Gold, N.D.; Martin, V.J.; Wollenweber, E.; Ibrahim, R.K. Sequential O-methylation of tricetin by a single gene product in wheat. Biochim. Biophys. Acta (BBA)-Gen. Subj. 2006, 1760, 1115-1124. [CrossRef]

91. Sun, J.; Liu, X.; Yang, T.; Slovin, J.; Chen, P. Profiling polyphenols of two diploid strawberry (Fragaria vesca) inbred lines using UHPLC-HRMSn. Food Chem. 2014, 146, 289-298. [CrossRef]

92. Jiang, R.-W.; Lau, K.-M.; Hon, P.-M.; Mak, T.C.; Woo, K.-S.; Fung, K.-P. Chemistry and biological activities of caffeic acid derivatives from Salvia miltiorrhiza. Curr. Med. Chem. 2005, 12, 237-246. [CrossRef]

93. Eklund, P.C.; Backman, M.J.; Kronberg, L.Å.; Smeds, A.I.; Sjöholm, R.E. Identification of lignans by liquid chromatographyelectrospray ionization ion-trap mass spectrometry. J. Mass Spectrom. 2008, 43, 97-107. [CrossRef] [PubMed]

94. Lang, R.; Dieminger, N.; Beusch, A.; Lee, Y.-M.; Dunkel, A.; Suess, B.; Skurk, T.; Wahl, A.; Hauner, H.; Hofmann, T. Bioappearance and pharmacokinetics of bioactives upon coffee consumption. Anal. Bioanal. Chem. 2013, 405, 8487-8503. [CrossRef] [PubMed]

95. Piccolella, S.; Crescente, G.; Volpe, M.G.; Paolucci, M.; Pacifico, S. UHPLC-HR-MS/MS-Guided recovery of bioactive flavonol compounds from greco di tufo vine leaves. Molecules 2019, 24, 3630. [CrossRef] [PubMed]

96. Simard, F.; Legault, J.; Lavoie, S.; Mshvildadze, V.; Pichette, A. Isolation and identification of cytotoxic compounds from the wood of Pinus resinosa. Phytother. Res. 2008, 22, 919-922. [CrossRef] [PubMed]

97. Rodríguez-Pérez, C.; Gómez-Caravaca, A.M.; Guerra-Hernández, E.; Cerretani, L.; García-Villanova, B.; Verardo, V. Comprehensive metabolite profiling of Solanum tuberosum L. (potato) leaves by HPLC-ESI-QTOF-MS. Food Res. Int. 2018, 112, $390-399$. [CrossRef] [PubMed]

98. Yang, S.; Wu, X.; Rui, W.; Guo, J.; Feng, Y. UPLC/Q-TOF-MS analysis for identification of hydrophilic phenolics and lipophilic diterpenoids from Radix Salviae Miltiorrhizae. Acta Chromatogr. 2015, 27, 711-728. [CrossRef]

99. Hou, S.; Zhu, J.; Ding, M.; Lv, G. Simultaneous determination of gibberellic acid, indole-3-acetic acid and abscisic acid in wheat extracts by solid-phase extraction and liquid chromatography-electrospray tandem mass spectrometry. Talanta 2008, 76, 798-802. [CrossRef] [PubMed]

100. Chen, X.; Zhu, P.; Liu, B.; Wei, L.; Xu, Y. Simultaneous determination of fourteen compounds of Hedyotis diffusa Willd extract in rats by UHPLC-MS/MS method: Application to pharmacokinetics and tissue distribution study. J. Pharm. Biomed. Anal. 2018, 159, 490-512. [CrossRef] [PubMed]

101. Toh, T.; Prior, B.; Van der Merwe, M. Quantification of plasma membrane ergosterol of Saccharomyces cerevisiae by direct-injection atmospheric pressure chemical ionization/tandem mass spectrometry. Anal. Biochem. 2001, 288, 44-51. [CrossRef]

102. Sun, S.; Gao, Y.; Ling, X.; Lou, H. The combination effects of phenolic compounds and fluconazole on the formation of ergosterol in Candida albicans determined by high-performance liquid chromatography/tandem mass spectrometry. Anal. Mol. 2005, 336, 39-45. [CrossRef]

103. Cai, Z.; Wang, C.; Zou, L.; Liu, X.; Chen, J.; Tan, M.; Mei, Y.; Wei, L. Comparison of Multiple Bioactive Constituents in the Flower and the Caulis of Lonicera japonica Based on UFLC-QTRAP-MS/MS Combined with Multivariate Statistical Analysis. Molecules 2019, 24, 1936. [CrossRef]

104. Perchuk, I.; Shelenga, T.; Gurkina, M.; Miroshnichenko, E.; Burlyaeva, M. Composition of Primary and Secondary Metabolite Compounds in Seeds and Pods of Asparagus Bean (Vigna unguiculata (L.) Walp.) from China. Molecules 2020, 25, 3778. [CrossRef]

105. Mittal, J.; Sharma, M.M. Enhanced production of berberine in In vitro regenerated cell of Tinospora cordifolia and its analysis through LCMS QToF. 3 Biotech 2017, 7, 25. [CrossRef]

106. Xie, J.; Ding, C.; Ge, Q.; Zhou, Z.; Zhi, X. Simultaneous determination of ginkgolides A, B, C and bilobalide in plasma by LC-MS/MS and its application to the pharmacokinetic study of Ginkgo biloba extract in rats. J. Chromatogr. B 2008, 864, 87-94. [CrossRef] [PubMed] 